\title{
Thermal Performance of the Hood River End-Use Metered Homes
}
N. E. Miller
R. G. Pratt

September 1990

Prepared for the Bonneville Power Administration under a Related Services Agreement with the U.S. Department of Energy under Contract DE-AC06-76RLO 1830

Pacific Northwest Laboratory Operated for the U.S. Department of Energy by Battelle Memorial Institute 


\title{
DISCLAIMER
}

This report was prepared as an account of work sponsored by an agency of the United States Government. Neither the United States Government nor any agency thereof, nor Battelle Memorial Institute, nor any of their employees, makes any warranty, expressed or implied, or assumes any legal liability or responsibility for the accuracy, completeness, or usefulness of any information, apparatus, product, or process disclosed, or represents that its use would not infringe privately owned rights. Reference herein to any specific commercial product, process, or service by trade name, trademark, manufacturer, or otherwise, does not necessarily constitute or imply its endorsement, recommendation, or favoring by the United States Government or any agency thereof, or Battelle Memorial Institute. The views and opinions of authors expressed herein do not necessarily state or reflect those of the United States Government or any agency thereof.

\author{
PACIFIC NORTHWEST LABORATORY \\ operated by \\ BATTELLE MEMORIAL INSTITUTE \\ for the \\ UNITED STATES DEPARTMENT OF ENERGY \\ under Contract DE-AC06-76RLO 1830
}

Printed in the United States of America

Available to DOE and DOE contractors from the

Office of Scientific and Technical Information, P.O. Box 62, Oak Ridge, TN 37831; prices available from (615) 576-8401. FTS 626-8401.

Available to the public from the National Technical Information Service, U.S. Department of Commerce, 5285 Port Royal Rd., Springfield, VA 22161.

NTIS Price Codes, Microfiche A01

Printed Copy

\begin{tabular}{cr}
\hline Price Code & Page Range \\
\hline A02 & $1-10$ \\
A03 & $11-50$ \\
A04 & $51-75$ \\
A05 & $76-100$ \\
A06 & $101-125$ \\
A07 & $126-150$ \\
A08 & $151-175$ \\
A09 & $176-200$ \\
A10 & $201-225$ \\
A11 & $226-250$ \\
A12 & $251-275$ \\
A13 & $276-300$ \\
A14 & $301-325$
\end{tabular}

\begin{tabular}{cc}
\hline Price Code & Page Range \\
\hline A15 & $326-350$ \\
A16 & $351-375$ \\
A17 & $376-400$ \\
A18 & $401-425$ \\
A19 & $426-450$ \\
A20 & $451-475$ \\
A21 & $476-500$ \\
A22 & $501-525$ \\
A23 & $526-550$ \\
A24 & $551-575$ \\
A25 & $576-600$ \\
A99 & $601-U p$
\end{tabular}


THERMAL PERFORMANCE OF THE HOOD RIVER END-USE METERED HOMES

N. E. Miller

R. G. Pratt

September 1990

Prepared for the Bonneville Power Administration under a Related Services Agreement with the U.S. Department of Energy Contract DE-AC06-76RLO 1830 


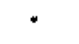




\section{SUMMARY}

The Hood River Conservation Project (HRCP) sponsored by the Bonneville Power Administration (Bonneville) involved the entire community of Hood River, Oregon, in one of the largest weatherization experiments ever conducted. Two goals were set in the experiment: to weatherize all homes to a predetermined cost-effectiveness limit and to gather the necessary data to assess the success of the retrofitting in terms of saved $\mathrm{kWh} / \mathrm{yr}$. The results reported here were commissioned by Bonneville as part of the effort to determine the thermal performance characteristics based on high time-resolution data. Results were then compared to results obtained from another methodology that uses billing data.

As part of the HRCP data collection, approximately 300 homes were enduse metered. These homes were predominately single-family homes but did include several multifamily units and about 50 manufactured homes. The enduse data, along with some survey data, form the data set for the thermal characterizations sumnarized in this report. In the thermal analysis described here, the metered data is used to characterize the heating load as a function of inside-outside temperature difference. An annualized estimated consumption (AEC) for electrical space heat for the home is estimated under a set of standard conditions. This quantity is ideally suited for pre- and post-retrofit comparisons as it is weather-normalized, adjusts for any changes in inside air temperature on a daily basis, and is not affected by intermittent wood use. Additional thermal parameters are derived from a robust linear fit of space heat to inside-outside temperature difference. Changes in inside operating temperatures and wood-stove usage patterns are also investigated. 
Previous analyses by others (Hirst 1987; Stovall 1987) indicated a discrepancy between the predicted savings (an average of $6,100 \mathrm{kWh} / \mathrm{yr}$ ) and the mean savings actually achieved of 2,600 kWh/yr. This work, although using a very different analytic technique and the end-use metered data, shows savings similar in magnitude to those previously found. The biggest difference is that this analysis specifically accounts for items that were used to discount some of the discrepancy between predicted and observed savings in the previous work.

The chief conclusions of this analysis for the sample of end-use metered homes characterized are as follows:

- The estimated total space heating consumption in the post-retrofit period dropped by $24 \%$ of the pre-retrofit level for the combined sample of homes. This represents a decrease in consumption of 2,432 $\mathrm{kWh} / \mathrm{yr}$ or $2.05 \mathrm{kWh} / \mathrm{ft}^{2}-\mathrm{yr}$. The change in single-family consumption was greater at $2,899 \mathrm{kWh} / \mathrm{yr}$ (or $2.24 \mathrm{kWh} / \mathrm{ft}^{2}-\mathrm{yr}$ ), close to a $30 \%$ drop compared to pre-retrofit levels. The percentage drop for the few multifamily units was similar to that of the single-family homes. The manufactured homes experienced about one-third the reduction of the single-family and multifamily units.

- Changes in heat loss coefficients (UA) and effective heatingdegree-days experienced by these homes, derived from the linear fits of the heating data to inside-outside temperature difference, show a magnitude of total savings similar to that of the AEC estimates. For the combined sample, the mean percentage change in the derived UAs and effective heating-degree-days are $20 \%$ and $5 \%$, respectively. Greater changes were noted for the single-family and multifamily units, less for the manufactured homes.

- Although a slight increase is noted in inside air temperatures over the two heating seasons, the rise is not large enough to conclude that the occupants raised their thermostat set points after weatherization. The weatherization of the homes could produce larger increases in inside air temperatures than those seen in the analyzed sample.

- Wood-stove usage dropped after installation of the weatherization measures. Although the total number of days of heater usage and the total number of days of wood-stove usage are fairly comparable across the heating seasons, the mean wood-stove signal, which is proportional to heat displacement, dropped in the post-retrofit period by about $27 \%$ for these homes. The mean heater usage, over the same period, dropped by about one-half as much. More of the savings appear to have been taken in reduced wood burning than in reduced use of permanent electrical space heating equipment. 


\section{CONTENTS}

SUMMARY ......................

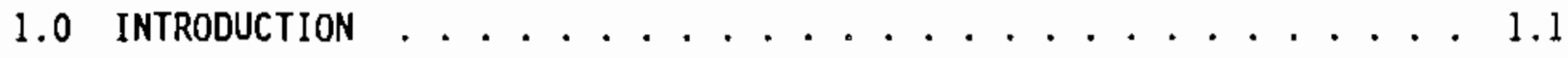

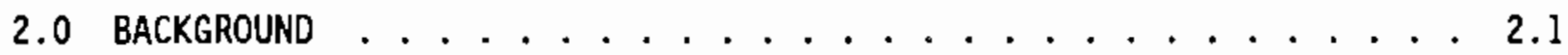

3.0 METHODOLOGY . . . . . . . . . . . . . . . . . 3.1

4.0 THERMAL PERFORMANCE ChARACTERIZATIONS . . . . . . . . . 4.1

4.1 CHANGES IN ESTIMATED ELECTRICAL SPACE HEATING CONSUMPTION * 4.1

4.2 PARAMETERS FROM THE LINEAR FIT . . . . . . . . . . 4.7

4.3 FURTHER EXPLORATION OF DERIVED PARAMETERS . . . . . . 4.10

4.4 INSIDE AIR TEMPERATURE . . . . . . . . . . . . 4.13

4.5 COMPARISON TO THE ElCAP HOMES ............ 4.16

5.0 WOOD-STOVE USAGE $\ldots \ldots \ldots \ldots \ldots . \ldots \ldots . \ldots . \ldots . \ldots$

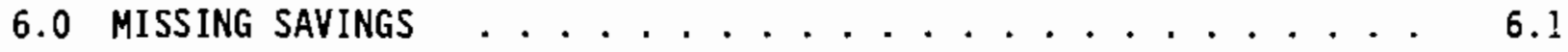

6.1 COMPARISON OF OUR RESULTS ................... 6.1

6.2 HYPOTHESES REgARDING THE MISSING SAVINGS . . . . . . . 6.10

7.0 CONCLUSIONS . . . . . . . . . . . . . . . . . 7.1

7.1 RECOMMENDED ADDITIONAL ANALYSES . . . . . . . . 7.2

8.0 REFERENCES . . . . . . . . . . . . . . . 8.1 


\section{FIGURES}

4.1 Annual Electric Space Heat Consumption Estimate for 113 Hood River Homes - Before and After Retrofitting . . . . . . . . 4.4

4.2 Pre- and Post-Retrofit Estimated Electrical Space Heat Consumption for Combined Sample: Single-Family, Multifamily, and Manufactured Homes. . . . . . . . . . . 4.5

4.3 Conditioned Floor Areas for the Analyzed Set of 113 Hood River Hones . . . . . . . . . . . . . . . . . 4.7

4.4 Slopes from the Robust Linear Fits for 113 Hood River Homes - Before and After Retrofitting ............ 4 4.8

4.5 As-Operated UAs for 113 Hood River Homes . . . . . . . . . . . . 4.9

4.6 Balance Delta Temperatures from the Robust Linear Fits for 113 Hood River Homes - Before and After Retrofitting . . . . 4.11

4.7 Mean Indoor Temperatures for 113 Hood River Homes Before and After Retrofitting ................ 4.14

5.1 Pre- and Post-Retrofit Mean Shares of Total Days for Each of Four Burning-Intensity Categories for $\mathbf{4 2}$ Single-Family Homes During the November 1 Through March 31 Period ................... . 5.3

6.1 House Geometry .................... . 6.13 


\section{$\underline{\text { TABLES }}$}

4.1 Summary of Pre- and Post-Retrofit Sample Means:

Estimated Electrical Space Heating Consumption

(kWh/ft2-yr)

4.2 Performance Statistics for 113 Hood River Homes . . . . . . . . . 4.6

4.3 Changes in Effective Heating Degree-Days Using Most

Typical Hood River Weather Year - Pre- and Post-Retrofit

Parameter Set.................. . . 4.12

4.4 Substitution by Building Type . . . . . . . . . . . . . . . 4.13

4.5 Mean Simulated Inside Air Temperature (September through May)

for Two Homes and Three Thermostat Controt Strategies . . . . . . 4.16

4.6 ELCAP and Hood River Homes' AEC Using

Seattle TMY Weather Data ................. 4.17

5.1 Hood River Single-Family Wood-Stove Usage Summary

for 43 Homes - -No Weather Normalization (November

through March)

5.2 Mean Number of Days in Each Burn Category for 43 Single-Fanily Homes

6.1 Building Classes Analyzed in Two Hood River Studies . . . . . . 6.1

6.2 Raw Data and Population Estimates . . . . . . . . . . . . 6.4

6.3 Comparison of Savings Estimates Based on Metered

Data and Fuel Bill Analysis . . . . . . . . . . . . . . 6.6

6.4 Adjusted Savings Estimates Based on Analysis of Metered and Billing Data . . . . . . . . . . . . . . . . 6.8

6.5 Summary of Adjusted Savings Estimates Based on Metered and Billing Data . . . . . . . . . . . . . . . 6.9

6.6 House Dimensions . . . . . . . . . . . . . . . . . 6.13

6.7 House Construction . . . . . . . . . . . . . . . . . 6.14

6.8 Zoning Strategy . . . . . . . . . . . . . . . . . . . 6.14

6.9 Heat Loss Coefficient Calculation as a Function of Insulation Level, Size, and Zoning Strategy. . . . . . . . 6.15

6.10 Heat Loss Coefficient as a Function of Insulation Level, Size, and Zoning Strategy 


\section{TABLES (Contd)}

\subsection{Effect of Zoning Strategy in Reducing Overall}

Heat Loss Coefficient . . . . . . . . . . . . 6.17

6.12 Reduction in Retrofit Benefits as a Result of Zoning Strategy ................. 6.19 


\subsection{INTRODUCTION}

The objectives of the Hood River Conservation Project (HRCP), conducted from 1983 through 1987, were to fully weatherize the community of Hood River, Oregon, and to gather the information required to compare actual savings to projected savings from that weatherization effort. This project, commissioned and funded by the Bonneville Power Administration (Bonneville), was successful in weatherizing the majority of homes in Hood River to a full predetermined cost-effectiveness limit. This report evaluates savings from that conservation effort.

As part of the data collection mandate, approximately 300 residences, including single-family homes (80\%), manufactured homes (17\%), and multifamily units (3\%), were end-use metered. Data were collected every 15-min. detailing total, space heating, and hot water (usually) electrical consumption. In about one-third of the sites, the hot water consumption data were replaced by data from a wood-stove sensor, whose magnitude is proportional to the heat output of the wood stove. In addition to the metered energy consumption data, the inside air temperature was also recorded. Weather stations in three locations provided meteorological data. Audit data were collected on the structural characteristics pre- and post-retrofit, as well as survey data on occupant attitudes and behaviors.

Between the spring of 1985 and early winter of 1986, the end-use metered homes had a variety of conservation measures installed. These measures were aimed at improving the thermal performance of the residential envelope and minimizing the heat loss and inefficient hot water usage in the homes. Enduse metered data were collected for the heating seasons before and after installation of these conservation measures. These data, along with some audit and survey data, have been used to characterize the end-use metered homes' pre- and post-retrofit, omitting the period during which the set of measures were installed. Space heating requirements and shell performance characterizations were derived for all the end-use metered homes when possible. 
Section 2.0 of this report summarizes previous analyses on Hood River savings. Section 3.0 describes the methodology used to estimate the space heat savings and changes in the thermal integrity of the residential envelope that occurred after installation of the weatherization measures. In Section 4.0, the changes in estimated electrical space heating consumption and other derived measures of thermal integrity are presented. Additionally, observed mean indoor air temperatures are compared; pre-retrofit comparisons are made to post-retrofit; and the average thermal performance of the Hood River Homes, post-retrofit, is compared to that of the End-Use Load and Consumer Assessment Program (ELCAP) monitored homes. Wood-stove usage patterns are examined in Section $\mathbf{5 . 0}$ for changes in intensity and frequency of wood-stove use. Section 6.0 provides a comparison savings analys is of the HRCP end-use metered homes and their actual retrofit savings against those projected at the inception of the project. Our conclusions are provided in Section 7.0. 


\subsection{BACKGROUND}

Several other studies of the HRCP have also been completed. Hirst (1987) used monthly billing data from the community of Hood River, collected both before and after installation of the weatherization measures, to evaluate the change in space heating consumption. Using the Princeton Scorekeeping Method (PRISM) (Fels 19B4) with the billing data from the pre-retrofit winter 1982 through 1983 and from the post-retrofit winter 1985 through 1986, Hirst found a mean total savings of 2,600 kWh/yr for 2,362 households (or a $35 \%$ decrease in the mean pre-retrofit level of consumption). This savings represents a 2.2 $\mathrm{kWh} / \mathrm{ft}^{2}$ of floor area drop in estimated pre-retrofit space heat consumption. These statistics were also reported according to housing type (single-family, multifamily, and manufactured home). Consumption dropped by $38 \%, 28 \%$, and 29\% for the single-family, multifamily, and manufactured home groups over pre-retrofit levels, respectively. This information is summarized in Table 2.1.

TABLE 2.1. Electricity Use and Savings for Homes Retrofit in the HRCP by Housing Type (Hirst 1987)

Housing Type

\begin{tabular}{|c|c|c|c|c|}
\hline Electricity Use, kWh/yr & Total & ingle-Family & Muttifamily & Manufactured Home \\
\hline $\begin{array}{r}\text { Total Use } \\
1982 / B 3 \\
1985 / 86\end{array}$ & $\begin{array}{l}18,600 \\
16,000\end{array}$ & $\begin{array}{l}20,400 \\
17,500\end{array}$ & $\begin{array}{r}10,700 \\
9,200\end{array}$ & $\begin{array}{l}19,200 \\
16,700\end{array}$ \\
\hline $\begin{array}{l}\text { Estimated Space Heat } \\
1982 / \mathrm{B3} \\
1985 / 86\end{array}$ & $\begin{array}{l}7,500 \\
4,800\end{array}$ & $\begin{array}{l}7,600 \\
4,600\end{array}$ & $\begin{array}{l}5,700 \\
3,700\end{array}$ & $\begin{array}{l}8,500 \\
6,300\end{array}$ \\
\hline $\begin{array}{l}\text { Decrease in } \\
\text { Total Bi1ling Data } \\
1982 / 83-85 / 86\end{array}$ & 2,600 & 2,900 & 1,600 & 2,500 \\
\hline $\begin{array}{l}\text { Decrease in Total } \\
\text { Compared to } 1982 / 83\end{array}$ & $35 \%$ & $38 \%$ & $28 \%$ & $29 \%$ \\
\hline Total Savings/ftz & 2.2 & 2.1 & 2.1 & 2.5 \\
\hline Number of Households & 2,362 & 1,545 & 396 & 421 \\
\hline
\end{tabular}


Because many of these homes relied upon a supplementary fuel source for a significant amount of space heat, Hirst also reports on the levels of estimated space heating savings for those homes that probably used electricity as their primary heating fuel. This designation was based upon occupant survey data. The magnitude of these savings tends to be larger than the savings observed in Table 2.1 , although the percent of change over pre-retrofit levels for the total and single family samples is essentially unchanged at $35 \%$ and $39 \%$, respectively. The absolute and percent savings rise dramatically for the multifamily sample and drop somewhat for the manufactured home sample. These numbers are summarized in Table 2.2.

The actual savings for the total sample of homes in Table 2.1 averaged $43 \%$ of the expected savings. Hirst attributed the discrepancy between actual savings $(2,600 \mathrm{kWh})$ and predicted savings from audits $(6,100 \mathrm{kWh})$ to typical differences between predicted and actual savings, the effect of reduced pre-program electricity use, decreases in wood use, and increased indoor temperature settings after the installation of the weatherization measures.

TABLE 2.2. Electricity Use and Savings as Main Fuel Source by Housing Type (Hirst 1987)

Housing Type

\begin{tabular}{|c|c|c|c|c|}
\hline Electricity Use, kwh/yr & Total & Single-Family & Multifamily & Manufactured Home \\
\hline $\begin{array}{r}\text { Total Use } \\
19 B 2 / 83 \\
1985 / 86\end{array}$ & $\begin{array}{l}21,000 \\
17,800\end{array}$ & $\begin{array}{l}24,400 \\
20,400\end{array}$ & $\begin{array}{r}10,600 \\
8,700\end{array}$ & $\begin{array}{l}20,800 \\
18,800\end{array}$ \\
\hline $\begin{array}{l}\text { Estimated Space Heat } \\
1982 / 83 \\
1985 / 86\end{array}$ & $\begin{array}{l}9,200 \\
6,600\end{array}$ & $\begin{array}{r}10,300 \\
7,000\end{array}$ & $\begin{array}{l}5,000 \\
3,200\end{array}$ & $\begin{array}{l}9,700 \\
8,100\end{array}$ \\
\hline $\begin{array}{l}\text { Decrease in } \\
\text { Total } 8111 \text { ing Data } \\
1982 / 83-85 / 86\end{array}$ & 3,200 & 4,000 & 1,900 & 2,000 \\
\hline $\begin{array}{l}\text { Percent Decrease } \\
\text { Compared to } 1982 / 83\end{array}$ & $35 \%$ & 39 & $38 \%$ & $21 \%$ \\
\hline Total Savings/ftz & 2.5 & 2.8 & 2.4 & 2.0 \\
\hline Number of Households & 615 & 362 & 115 & 138 \\
\hline
\end{tabular}


Stovall (1987) also used the end-use metered data from the Hood River homes to study the change in the HRCP peak load, rather than the overall energy savings. She concluded that single-family homes save an average of $24 \%$ of their space heating load. The manufactured home sample saved only an average of $8 \%$ on their space heating load.

The analysis reported here uses the same load data collected from the end-use metered homes that was available to Stovall (1987). The primary objective of this work is to estimate overall energy savings using a method that provides a weather-normalized estimate between the pre- and postretrofit years. This estimate automatically accounts for changes in indoor temperature strategies (should they occur), and provides a savings estimate not reduced by the intermittent use of supplementary fuel sources such as wood. Secondary objectives of this work are to study changes over the preand post-retrofit heating seasons for mean indoor air temperatures and woodstove usage patterns. 


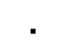

. 


\subsection{METHODOLOGY}

For the purpose of this analysis, the heating season is defined as September through May. In some cases this heating season window is shortened to avoid the time of the retrofit installation. The thermal analysis characterizations for the end-use metered Hood River homes are based on an analysis of daily average inside temperature, daily average outside temperature, and daily electrical space heating consumption. For homes with wood-stove sensors, days with wood use are omitted from the analysis. For those homes with wood-burning equipment and no wood-stove sensor, all days are initially included in the analysis. Exclusion from further analysis occurs if moderate-to-heavy wood use is noted in the data for these sites. An inside temperature, averaged over the heating season, is also computed as a measure of occupant control strategy. For each structure, several quantities are derived from the inside-outside temperature difference and the heating data. These measures, described below, include an annual estimate of electrical space heating requirements and a slope and balance temperature difference.

The empirical measure we consider most powerful for comparing structures is the annualized estimated consumption (AEC) for space heating. The AEC is derived separately for each structure. This quantity corrects to the first order for daily changes in inside-outside temperature and thus, is ideally suited for evaluating pre- and post-retrofit performance changes in the Hood River homes. The AEC is derived by fitting a smooth curve to the scatter plot of daily space heating energy consumption versus inside-outside temperature difference. The resulting curve, along with the measured inside temperature (or any desired inside temperature) and outdoor temperatures from a selected reference weather year, can be used to estimate the typical annual space heating requirements for the structure, assuming that the level of internal and solar heat gain is equal to that observed over the data collection interval. 
A slope and balance temperature difference is computed from a robust linear fit of the daily space heating data to the inside-outside temperature difference. The slope can be interpreted as the quotient of the conductive heat loss coefficients (UA) and the heating system efficiency and thus, can be viewed as a measure of a building's thermal integrity. The balance temperature difference can be interpreted as the average inside-outside temperature difference that a building can support without use of the space heating equipment, given its average level of internal and solar heat gains.

The sample selected for analysis here contains 113 homes-- 82 singlefamily, 7 multifamily homes, and 24 manufactured homes. It is possible to reliably characterize 126 homes in the pre-retrofit heating season and 121 in the post-retrofit heating season. However, because this report makes before and after comparisons, only those homes with characterizations common to both the 1984 through 1985 and 1985 through 1986 heating seasons are selected for final inclusion in results. Close to 60 sites with monitored wood stoves are excluded from the results. After removal of the monitored wood-use days for these homes, too few days are left to reliably characterize the heating load of the structure across the appropriate range of temperature differences. Few homes are excluded for having inconclusive or missing data. The loss of the balance of the sites is because of dependence on supplementary fuel sources. Moderate-to-heavy wood use appears to be the chief occupant behavior leading to the exclusion of sites from the final analys is summary. These assumptions are based upon a comparison of survey data on occupant's wood use habits with scatter plots of heater load versus inside-outside temperature difference.

All calculations are performed using techniques that are resistant to the effect of outlier points, such as isolated vacation days. For a more detailed discussion of the analytic technique see Drost et al. (1987). The derived measures of thermal performance for the end-use metered Hood River homes are

- not affected by intermittent use of wood heating equipment because these days are removed from the analysis

- corrected for changes between site heating seasons in inside temperature as refiected in the measured data 
- corrected for weather variations from one year to the next by using a given reference weather year to derive the annualized electrical space heating estimates for both pre- and post-retrofit periods.

Because all wood use days are removed prior to the parameter derivation, the sumnary numbers produced in this report are not lessened by the rather extensive use of wood in the Hood River community. Therefore, the AEC savings are comparable to the original savings estimates that ignored the possibility of wood use. Changes in mean inside air temperature for the main living area are directly accounted for in the derived estimates. However, because no multiple sensors are in place for the residences studied, room closures and zoning are not corrected for in this analysis. If the occupants were closingoff rooms before the installation of retrofit measures and then stopped postretrofit period, the change in structural thermal integrity over the two heating seasons could be underestimated. 
. 


\subsection{THERMAL PERFORMANCE CHARACTERIZATIONS}

The results of the thermal performance characterizations for the various building types of 113 Hood River homes are summarized in this section across the various building types. The differences in the annual estimated electrical space heat consumption for various weather years are examined. Changes in the parameters from the robust linear fit, which tracks changes in the residential shell performance, are also presented. The relation between the $A E C$ and parameters from the linear fit are examined for consistency. The thermal performance statistics for the 113 Hood River sample homes are then compared to those derived for the End-Use Load and Consumer Assessment Program (ELCAP) homes. This program is conducted for Bonneville by the Pacific Northwest Laboratory (PNL), (a).

\subsection{CHANGES IN ESTIMATED ELECTRICAL SPACE HEATING CONSUMPTION}

Several different weather years and two separate occupant control strategies are used to compute estimates of electrical space heating consumptions for the residences. Estimates are performed using typical meteorological year (TMY) data for Seattle, Washington; Spokane, Washington; Missoula, Montana; and Portland, Oregon. Because no TMY data exists for Hood River, several National Oceanographic and Atmospheric Administration weather years from Hood River are used. The years used (winter only) and associated heating-degree days (HDD) to base $65^{\circ} \mathrm{F}$ are:

1978 through $1979-\cdots>6134 \mathrm{HDD}$
1976 through $1977--->5502 \mathrm{HDD}$
1980 through $1981--->5142 \mathrm{HDD}$

These years are selected for Hood River as they represent the coldest, most typical, and warmest years out of the last 10 years, and in some sense, provide upper and lower bounds on potential savings available from the Hood River retrofit.

(a) The Pacific Northwest Laboratory (PNL) is operated for the Department of Energy (DOE) by Battelle Memorial Institute (BMI) under Contract DE-ACO676RLO 1 B30. 
Table 4.1 displays the AEC results averaged across the single-family, manufactured home, multifamily, and combined samples. The sample means are displayed before and after the installation of conservation measures using the 7 weather years described above.

The numbers reported are in $\mathrm{kWh} / \mathrm{ft}^{2}$ of conditioned floor area. To produce these estimates, the occupants' mean seasonal inside air temperatures were used. The most typical weather year from Table 4-1 indicates that the combined sample of homes showed a $24 \%$ reduction in $\mathrm{kWh} / \mathrm{ft}^{2}-\mathrm{yr}$ in the post-retrofit heating season. Single-family dwellings demonstrate a reduction in the pre-retrofit level of consumption of $30 \%$. The small sample of multifamily units shows a change of $31 \%$. Manufactured homes show the poorest results with an overall difference of $11 \%$.

Figure 4.1 displays the distributions of floor-area-normalized AECs in the form of box and whisker plots. The median AEC for each class of buildings is represented by the line drawn through the middle of the appropriate box. The lower and upper ends of the box represent the first and third quartiles of the data, respectively. Whiskers are drawn outward to show the outer ranges of the data, while asterisks indicate possible outliers. Significant postretrofit reductions in estimated heating consumption are evident for all building types.

Figure 4.2 displays these data in a different format. The pre-retrofit AEC of each of the 113 analyzed homes is plotted against its corresponding post-retrofit AEC. Note, that while $90 \%$ of the homes lie below the line of equal pre- and post-retrofit consumption (indicating decreased post-retrofit consumption), $10 \%$ of the homes showed either an increase or no change in annual space heating estimates. 
IABLE 4.1. Summary of Pre- and Post-Retrofit Sample Means:
Estimated Electric Space Heat ing Consumption (kWh/ft ${ }^{2}-\mathrm{yr}$ )
(Samples Based on Average Measured Inside Air Temperature)

SAINTE

\begin{tabular}{|c|c|c|c|c|c|c|c|c|c|c|c|c|c|c|c|c|}
\hline \multirow{2}{*}{$\begin{array}{l}\text { Teather } \\
\text { Year }\end{array}$} & \multicolumn{4}{|c|}{ Conbined } & \multicolumn{4}{|c|}{ Single-fanily } & \multicolumn{4}{|c|}{ Hanufactured } & \multicolumn{4}{|c|}{ Uulti-Fanily } \\
\hline & Pre & Post & $\Delta$ & $\Delta$ & Pre & Post & $\underline{\Delta}$ & $\Delta$ & Pre & Post & $\Delta$ & $\Delta$ & Pre & Post & $\Delta$ & $\Delta x$ \\
\hline $\begin{array}{l}\text { Hood Aiver } 76-79 \\
6134 \text { HCD } \\
\text { (coldest) }\end{array}$ & 9.57 & 7.35 & -2.22 & -23 & C. 55 & 6.12 & -2.43 & -28 & 13.17 & 11.78 & -1.39 & -11 & 9.25 & 6.57 & -269 & -29 \\
\hline $\begin{array}{l}\text { Hood River } 76-71 \\
\text { S582HDD } \\
\text { (ecst typical) }\end{array}$ & 8. 16 & 6.41 & -2.85 & -24 & 7.56 & 6. 32 & -2.24 & -30 & 11.67 & 10.38 & -128 & -11 & 8. 12 & 5.64 & -247 & -36 \\
\hline $\begin{array}{l}\text { Hood River } \theta \theta-\theta 1 \\
\text { SidzHDD } \\
\text { (marnest) }\end{array}$ & 7.62 & 5.74 & -188 & -25 & 6.80 & 1.75 & -2.06 & -38 & 1051 & 9.34 & -1.17 & -11 & 7.28 & 5.62 & -2.25 & -31 \\
\hline Seattle INYY & 1.77 & 5.83 & -1.94 & -25 & 694 & 181 & -2.13 & -31 & 1070 & 951 & -1.19 & -11 & 7.15 & 5. 11 & -2.34 & -31 \\
\hline Spokane TuY & 11.16 & 8.60 & -2.57 & -23 & 996 & 117 & -279 & -28 & 1510 & 13.76 & -1.63 & -11 & 10.71 & 7.63 & -3.88 & -29 \\
\hline Hissoula Tur & 12.91 & 9.98 & -2.93 & -23 & 11.52 & O 33 & -319 & -28 & 1779 & 15.93 & -1.86 & -10 & 12.14 & 6. 91 & -3.52 & -28 \\
\hline Portland TuY & 6.71 & 5.62 & -1.69 & -25 & 5.99 & 4.14 & -185 & -31 & 924 & 8. 21 & -1.03 & -11 & 613 & 1. 39 & -284 & -32 \\
\hline
\end{tabular}

$\Delta=$ Post-Pre $\Delta x=1030$ (Post-Pre)/Pre 


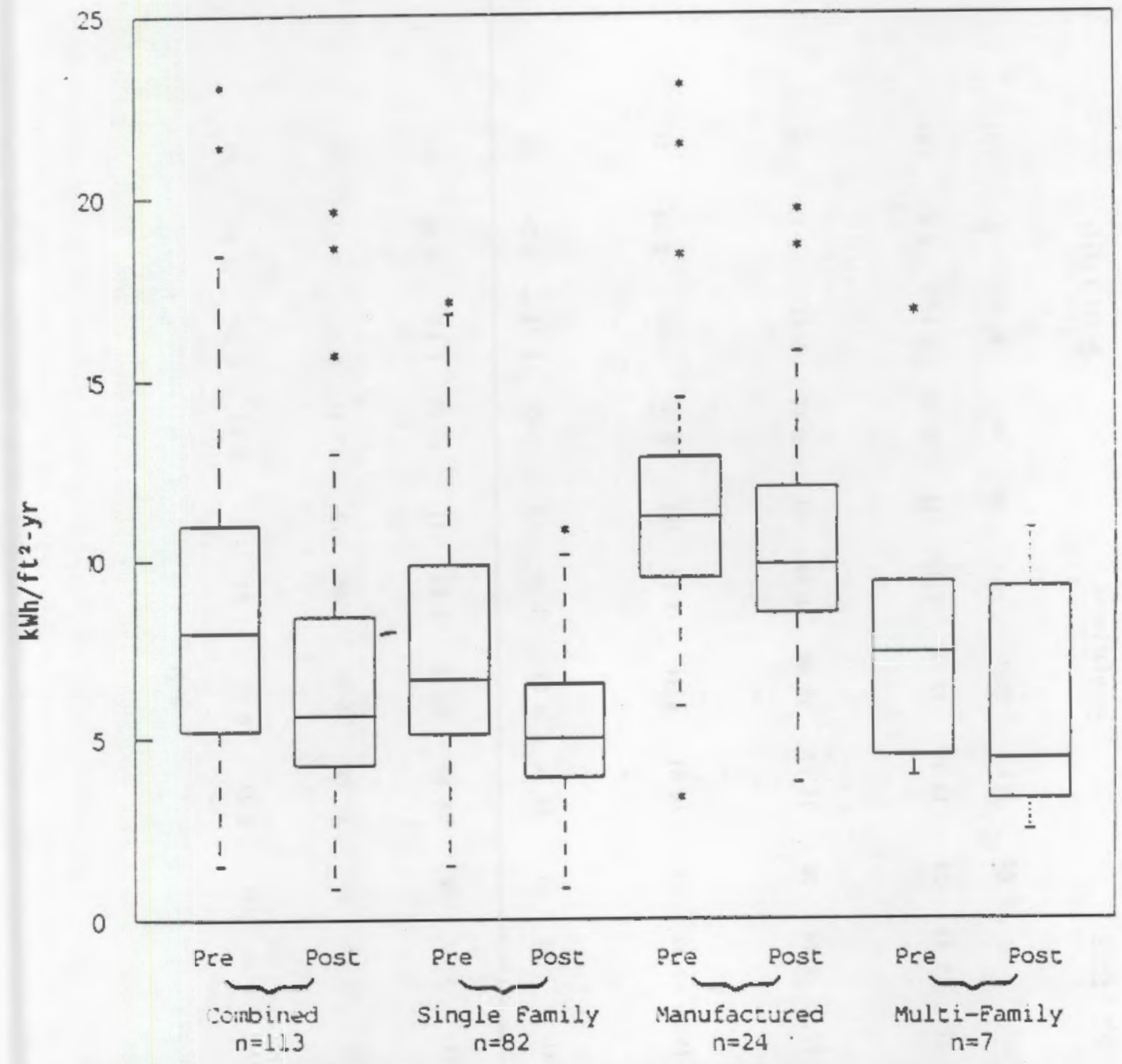

FIGURE 4.1. Annual Electric Space Heat Consumption Estimate for 113 Hood River Homes - Before and After Retrofitting

Table 4.2 displays a performance summary of the various statistics for the 113 Hood River homes. The annual space heating estimates (in the first two rows) are derived by using the occupants measured indoor temperatures and Hood River's most typical weather year. The mean of the total estimated space heating requirements is displayed by housing type in Table 4.2. The preretrofit mean AEC value of $10,111 \mathrm{kWh} / \mathrm{yr}$ for the combined sample drops to 7679 $\mathrm{kWh} / \mathrm{yr}$ in the post-retrofit period. This represents a change of $2432 \mathrm{kWh} / \mathrm{yr}$, or a $24 \%$ decrease. The change in estimated total space heating consumption 


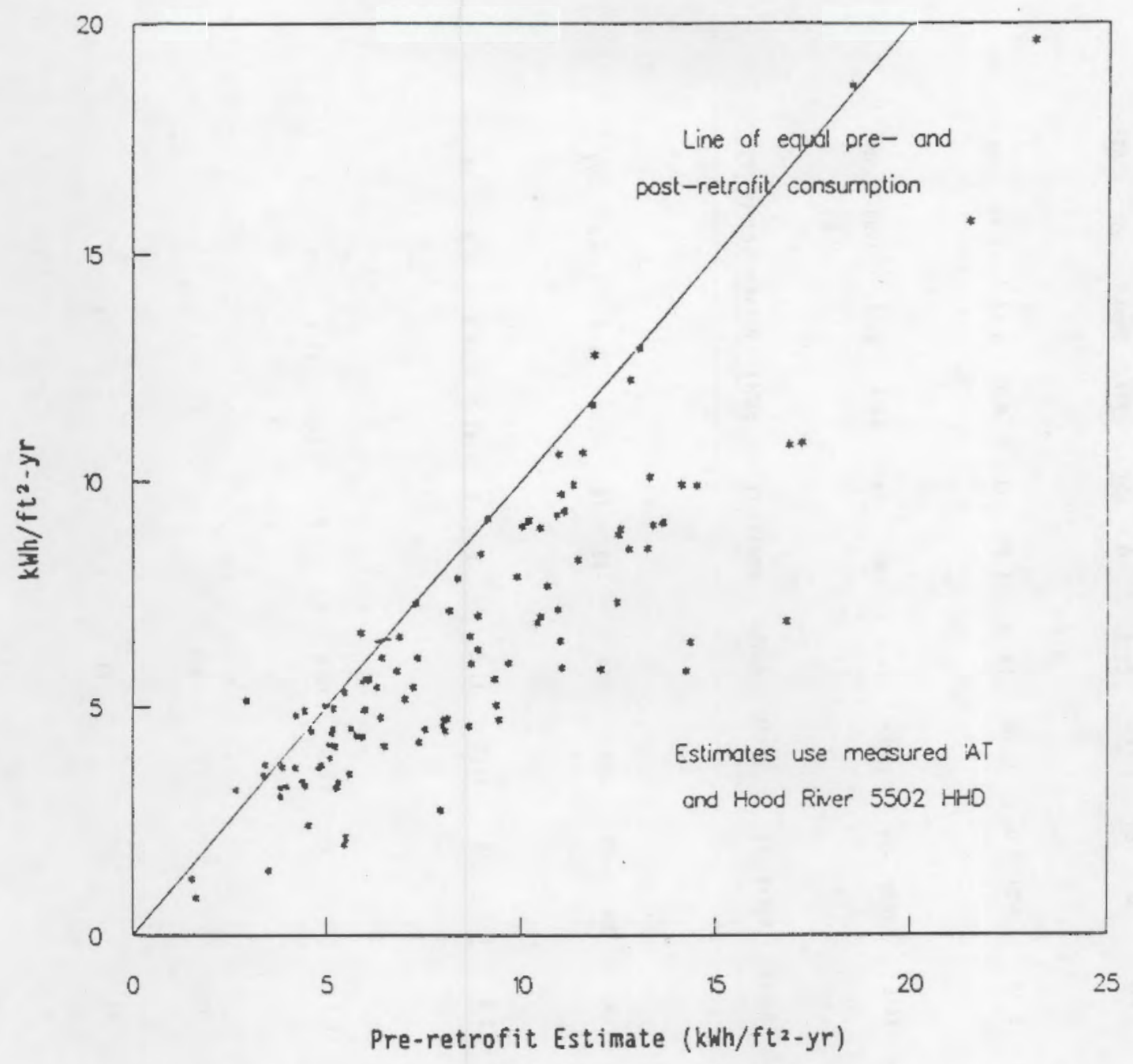

FIGURE 4.2. Pre- and Post-Retrofit Estimated Electrical Space Heat Consumption for Combined Sample: Single-Family, Multifamily, and Manufactured Homes

for the single-family, multifamily, and manufactured home samples represents decreases of $28 \%, 10 \%$, and $30 \%$ respectively, in the pre-retrofit consumption level.

The distribution of floor areas for the various building types is illustrated in Figure 4.3. The average floor area for the few multifamily units is $60 \%$ of that for the mean of the single-family homes. The mean manufactured home size tends to be about two-thirds the size of the mean floor area for the single-family dwellings. Although considerable variation exists 


\section{IABLE 4.2. Performance Statistics for 113 Hood River Homes}

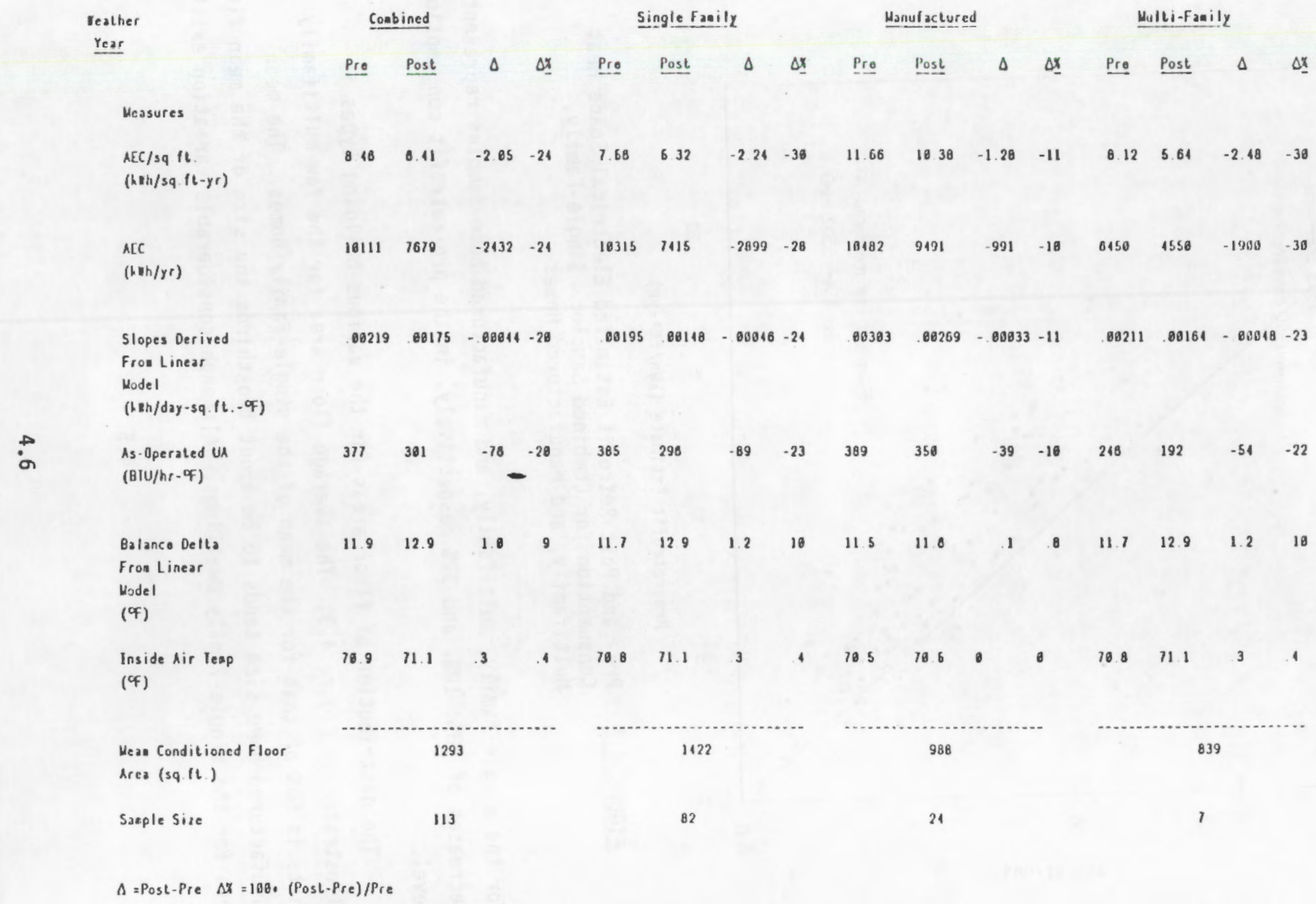




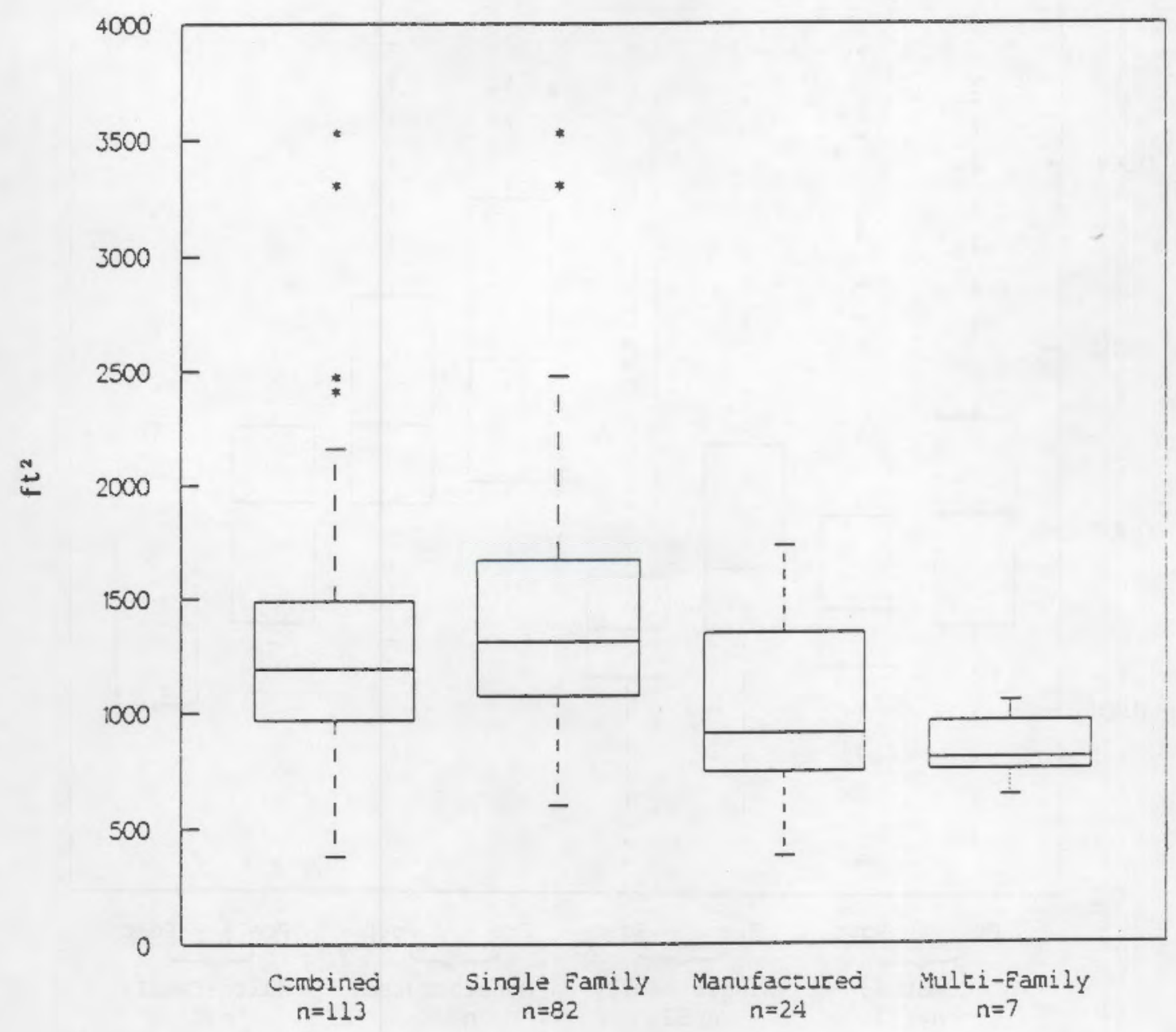

FIGURE 4.3. Conditioned Floor Areas for the Analyzed Set of 113 Hood River Homes

in housing size within both the single-family and manufactured-home groups, comparable changes for total AEC and floor area normalized AEC are observed between the post- and pre-retrofit heating seasons for homes in each of these building classes.

\subsection{PARAMETERS FROM THE LINEAR FIT}

The slope from a linear fit of daily space heating consumption data to inside-outside temperature difference can be viewed as a measure of a structure's thermal integrity. The distribution of the slopes by building 


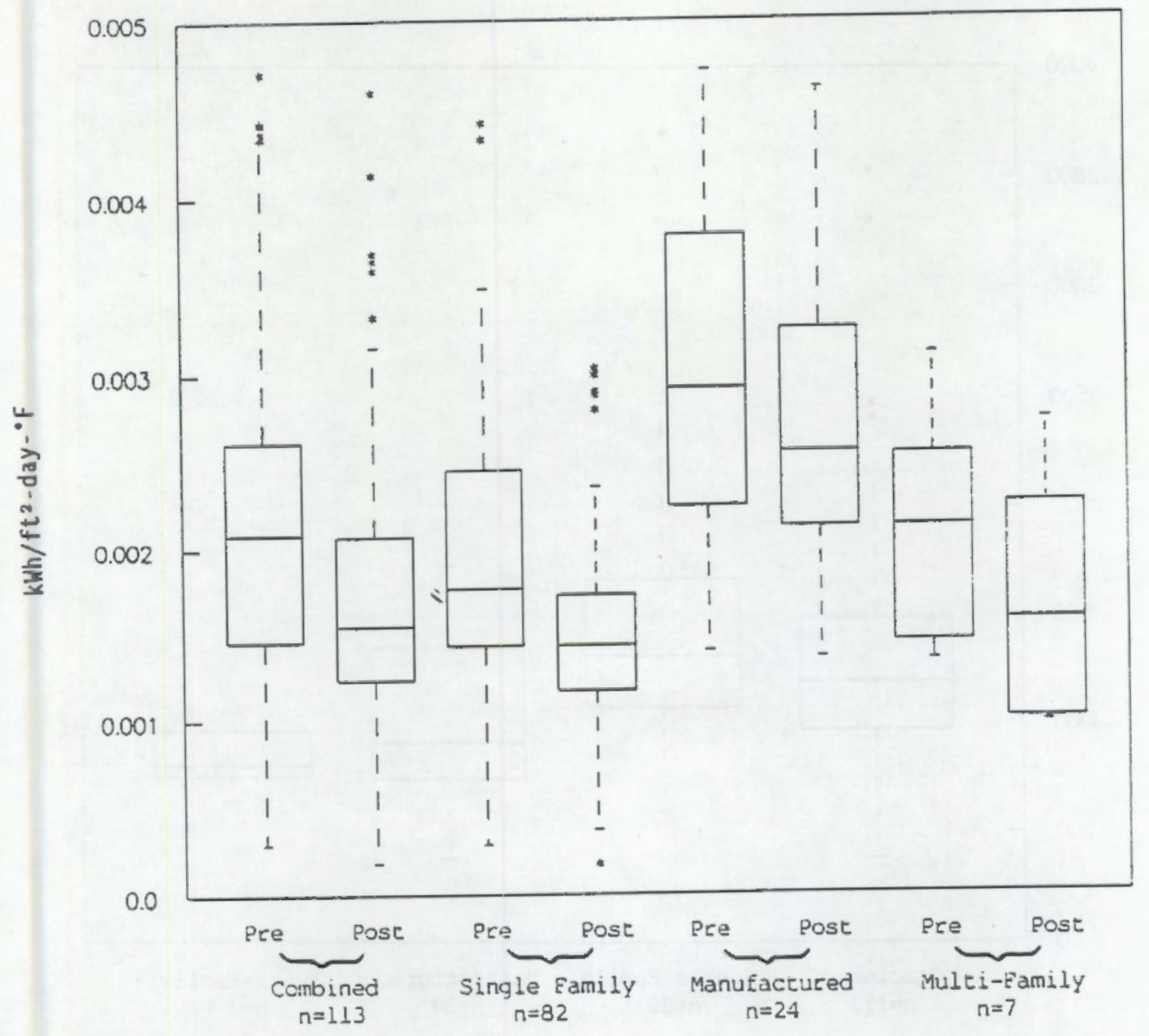

FIGURE 4.4. Slopes from the Robust Linear Fits for 113 Hood River Homes Before and After Retrofitting

type, before and after retrofit, are displayed in Figure 4.4. The overall change in post-retrofit slopes for the combined sample is approximately $0.00044 \mathrm{kWh} / \mathrm{ft}^{2}-\mathrm{day}^{\circ} \mathrm{F}$ or $20 \%$ of the pre-retrofit level. The single-family and multifamily groups show greater shell improvement than the manufactured homes. This is evidenced by the larger decrease in slope, both in absolute and percentage terms.

In discussing the estimated annual electrical space heating consumption it is useful to consider both $\mathrm{kWh} / \mathrm{ft}^{2}-\mathrm{yr}$ and total $\mathrm{kWh} / \mathrm{yr}$. A similar exercise is performed for the slopes. By removing the floor area normalization and 
applying a change of units, the slope from the robust linear fit is transformed to an "as-operated" heat loss coefficient for the residential envelope. Because this coefficient can be interpreted as a measure of the resistance of the envelope to heat transport, changes in the as-operated UAs are examined across building types for the pre- and post-retrofit heating seasons. Increased thermal resistance is indicated by a downward shift in the UA.

Figure 4.5 compares the before and after as-operated UAs for the analyzed end-use metered homes. In this figure, the single-family homes are

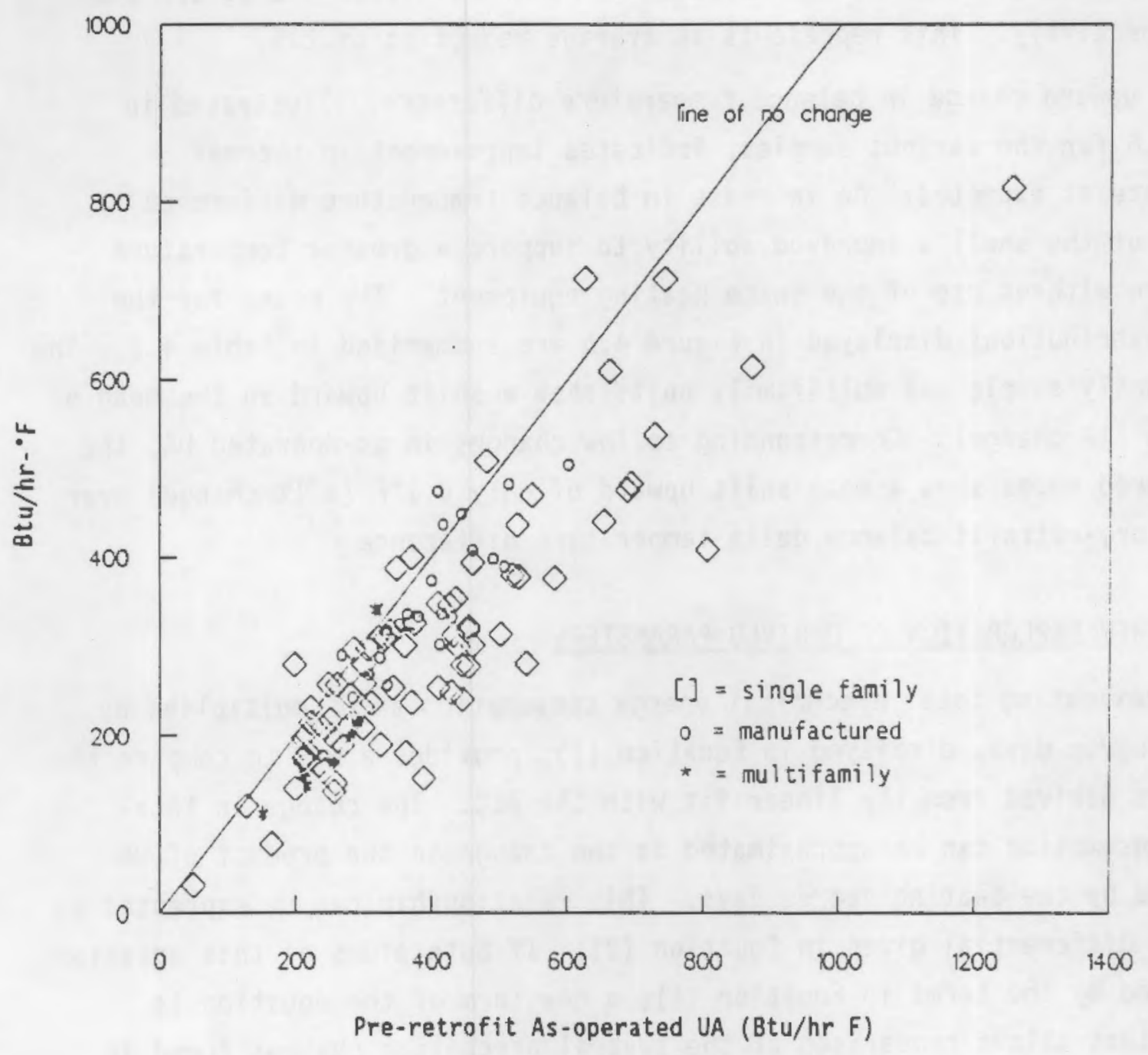

FIGURE 4.5. As-Operated UAs 113 Hood River Homes 
noted with diamonds, multifamily homes with squares, and manufactured homes with asterisks. The line of equal pre-and post-retrofit as-operated UAs is drawn to enhance before and after comparisons. The as-operated UA is computed from those slopes illustrated in Figure 4.4 but also includes multiplication by floor area and a conversion factor to change the $\mathrm{kWh} / \mathrm{ft}^{2}$-day ${ }^{\circ} \mathrm{F}$ to $B t u / h r-{ }^{\circ} \mathrm{F}$. The manufactured homes, as a group, cluster more closely to the identity line than do the single-family units. The change in as-operated UA for the manufactured homes represents a $10 \%$ reduction, compared to a change of $23 \%$ for single-family homes and $22 \%$ for multifamily units. The mean combined UA, pre- and post-retrofit, can be read from row 4 of Table 4.2 at 377 and 301 , respectively. This represents an average reduction of $20 \%$.

The upward change in balance temperature difference, illustrated in Figure $\mathbf{4 . 6}$ for the various samples, indicates improvement in thermal performance as expected. An increase in balance temperature difference is evidence of the shell's improved ability to support a greater temperature difference without use of the space heating equipment. The means for the sample distributions displayed in Figure 4.6 are summarized in Table 4.2 . The single-family sample and multifamily units show a shift upward in the mean of $1.2^{\circ} \mathrm{F}$ (an $11 \%$ change). Corresponding to. low changes in as-operated UA, the manufactured homes show a mean shift upward of only $0.1^{\circ} \mathrm{F}$ (a $1 \%$ change) over the mean pre-retrofit balance delta temperature difference.

\subsection{FURTHER EXPLORATION OF DERIVED PARAMETERS}

Approximating total electrical energy consumption as UA multiplied by heating-degree days, displayed in Equation (1), provides a way to compare the parameters derived from the linear fit with the AEC. The change in total energy consumption can be approximated as the change in the product of UA multiplied by the heating-degree days. This relationship can be expressed as the total differential given in Equation (2). If both sides of this equation are divided by the terms in Equation (1), a new form of the equation is produced that allows comparison of the several percentage changes found in Table 4.2. 


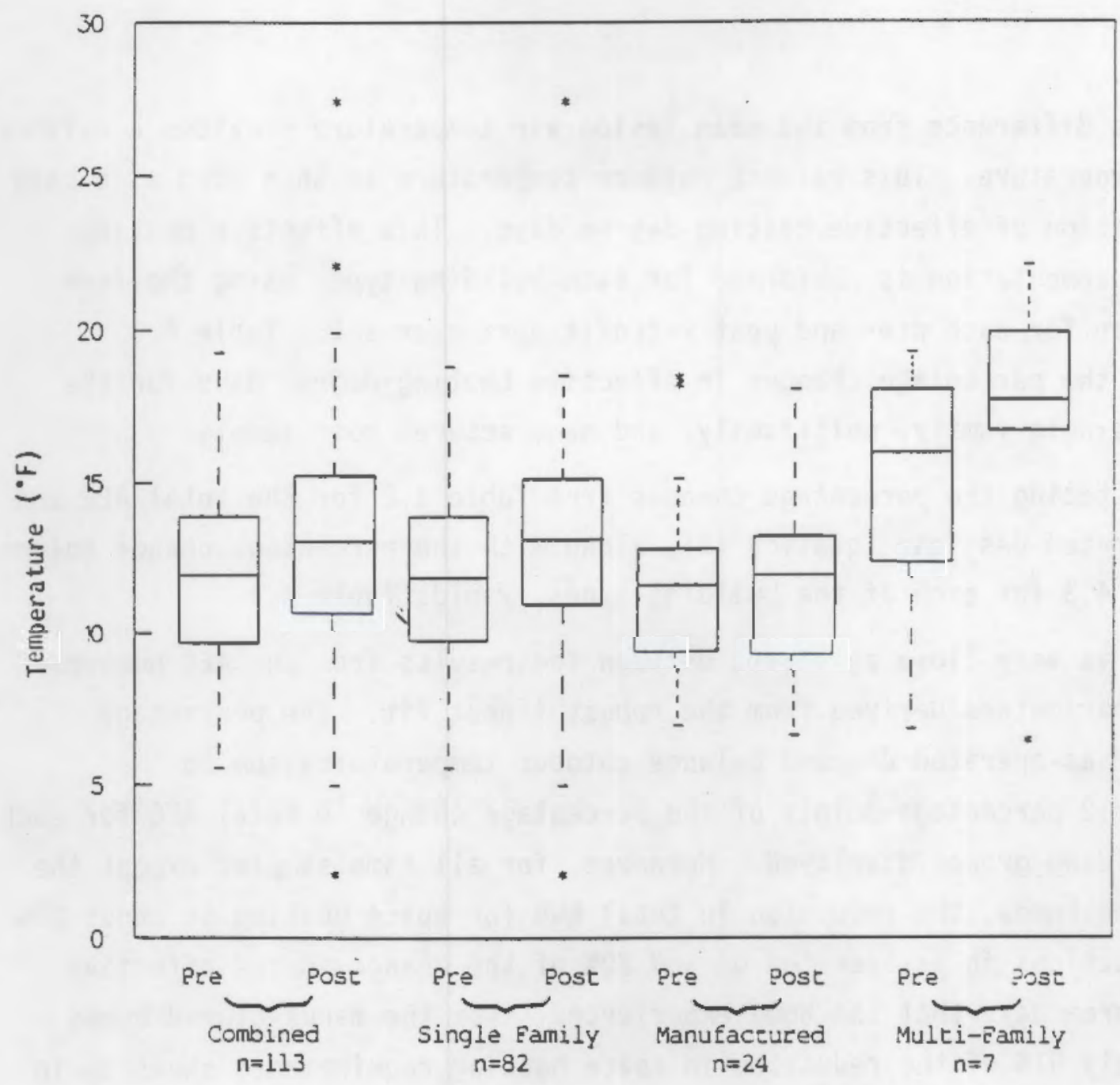

FIGURE 4.6. Balance Delta Temperatures from the Robust Linear Fits for 113 Hood River Homes - Before and After Retrofitting

$$
\begin{aligned}
E & =U A * H D D \\
d(E) & =d(U A) \star H D D+d(H D D) * U A \\
d(E) / E & =d(U A) / U A+d(H D D) / H D D
\end{aligned}
$$

In Equation (3), the term $d(E) / E$ is interpreted as the percentage change in total consumption for the two heating season estimates. The term $d(U A) / U A$ is interpreted as the percentage change in as-operated UA. The percentage change in effective heating-degree days, represented by the term $d(H D D) / H D D$, must be computed from the balance temperature difference, the mean inside air temperature, and the Hood River weather year. Subtracting the balance

\subsection{1}


temperature difference from the mean inside air temperature provides a balance outdoor temperature. This balance outdoor temperature is then used as a base for computation of effective heating-degree days. This effective heatingdegree day computation is performed for each building type, using the same weather year for each pre- and post-retrofit parameter set. Table 4.3 summarizes the percentage changes in effective heating-degree days for the combined, single-family, multifamily, and manufactured home sample.

Substituting the percentage changes from Table 4.2 for the total AEC and the as-operated UAs into Equation (3), along with the percentage change column from Table 4.3 for each of the building-types, yields Table 4.4.

There is very close agreenent between the results from the AEC numbers and those parameters derived from the robust linear fit. The percentage changes for as-operated UAs and balance outdoor temperatures sum to within 1 or 2 percentage points of the percentage change in total AEC for each of the building groups displayed. Moreover, for all home samples except the manufactured homes, the reduction in total $\mathrm{kWh}$ for space heating is about $80 \%$ of the reductions in as-operated UA and $20 \%$ of the change in the effective heating-degree days that the home experiences. For the manufactured homes approximately $91 \%$ of the reduction in space heating requirements shows up in the as-operated UA. Not only do the manufactured homes experience less savings in AECs than do the single-family and the multifamily units, but the savings that do occur are in different proportions of the UA and the effective HDD.

TABLE 4.3. Changes in Effective Heating Degree-Days Using Most Typical Hood River Weather Year - Pre- and Post-Retrofit Parameter Set

\begin{tabular}{|c|c|c|c|c|c|}
\hline $\begin{array}{l}\text { Building } \\
\text { Type }\end{array}$ & $\begin{array}{l}\text { Bala } \\
\text { Outdoor } \\
\text { Pre } \\
\end{array}$ & $\begin{array}{l}\text { ance } \\
\text { Temp ( }\left({ }^{\circ} F\right) \\
\text { Post } \\
\end{array}$ & $\begin{array}{l}\text { Effective } \\
\text { Pre }\end{array}$ & $\begin{array}{l}\text { HDD } \\
\text { Post } \\
\end{array}$ & $\begin{array}{l}\text { Percentage } \\
\text { Change }\end{array}$ \\
\hline $\begin{array}{l}\text { Combined } \\
\text { Single Family } \\
\text { Manufactured } \\
\text { Multifamily }\end{array}$ & $\begin{array}{l}59.0 \\
59.1 \\
59.0 \\
59.1\end{array}$ & $\begin{array}{l}58.2 \\
58.2 \\
58.9 \\
58.2\end{array}$ & $\begin{array}{l}3800 \\
3826 \\
3800 \\
3826\end{array}$ & $\begin{array}{l}3599 \\
3599 \\
3775 \\
3599\end{array}$ & $\begin{array}{l}5.3 \\
5.9 \\
0.7 \\
5.9\end{array}$ \\
\hline
\end{tabular}


TA8LE 4.4. Substitution by Building Type

$$
d(E) / E=d(U A) / U A+d(H D D) / H D D
$$

Building Type $\underline{d(E) / E} \quad \underline{d(U A) / U A+d(H D D) / H D D} \quad \underline{d(U A) / U A} \quad \underline{d(H D D) / H D D}$ Combined 24 Single Family 30 Multifamily 30 Manufactured 11

25

29

28

11
20

23

22

10

5
6
6
1

\subsection{INSIDE AIR TEMPERATURE}

When a major home-tightening program results in less savings than was originally anticipated, it is often postulated that occupants, aware that their homes are now more energy-efficient, become less concerned with energy conservation and negate some of the energy savings by increasing the use of comfort and convenience devices. "Takeback," as this phenomenon is commonly termed, can take on several forms but is most commonly attributed to changes in zoning behavior or thermostat usage. Zoning is the practice of not heating unused rooms. An occupant who previously closed off unused rooms might cease to do so when the house becomes more efficient. Similarly, thermostat settings might be increased, keeping the homes warmer after the retrofits.

The issue of zoning is difficult to resolve because of limitations of the data collected from each house. An in-depth discussion of zoning appears in Section 6.0 and presents a plausible explanation of how the unrealized HRCP savings might be related to zoning behavior. Thermostat settings are investigated more easily because each end-use metered home has an indoor air temperature sensor. The results of the thermostat investigations are presented in this section.

Inspection of indoor temperature data does not reveal conclusive evidence that occupants increased temperatures in the main living area for these homes. Figure 4.7 displays the distribution of the mean heating season indoor temperature for each sample both before and after retrofit. Although there is a slight upward trend in the median, the mean change for the combined home sample is only $0.3^{\circ} \mathrm{F}$. To better understand what magnitude of change in inside 


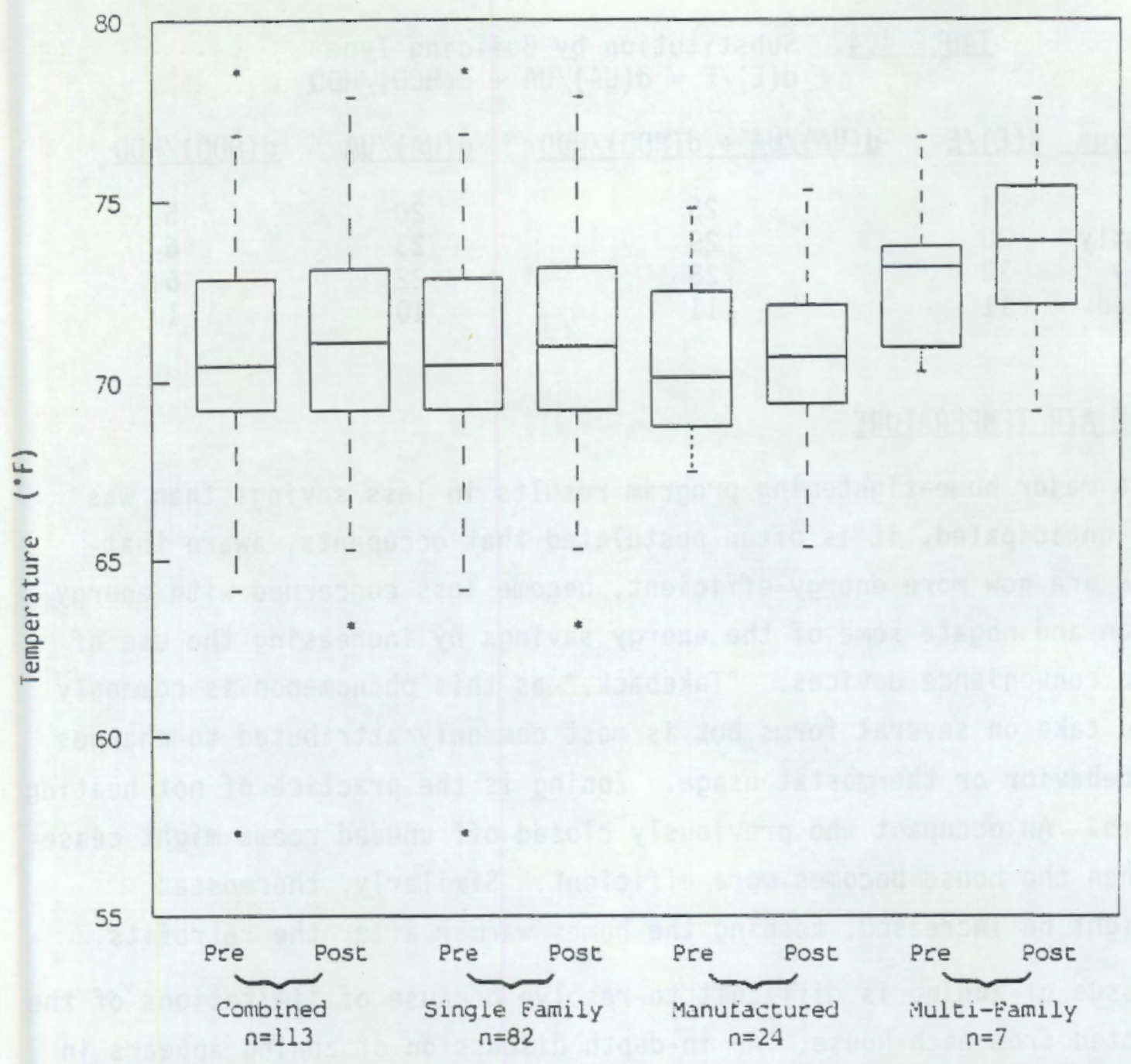

FIGURE 4.7. Mean Indoor Temperatures for 113 Hood River Homes Before and After Retrofitting

air temperature would be indicative of changes in thermostat usage, thermostat set points were investigated in on several thermal simulations. The goal of the simulations was to produce an estimate of inside temperature over the heating season given a set of UAs similar to the pre- and post-retrofit as-operated UAs. We constructed a simple thermal network model representing a single-zone building. The model includes a single indoor air node, a pure resistance to heat flow between inside and outside, and a thermal mass node connected to the air via a simple thermal resistor. Using finite difference techniques, we modeled the indoor temperature assuming the house was equipped 
with a thermostatically controlled heating system. The thermal mass parameters used in the simulation were derived from regression analyses of metered data from several homes and represent thermal storage capacities typical of residential structures.

In the absence of Hood River TMY data, Portland TMY outside weather and solar data were used in the test cases. Using Portland TMY data tends to underestimate the changes in mean inside air temperature that would be observed using Hood River data because Portland has less HDD than Hood River.

The home is initially simulated with a UA of $385 \mathrm{Btu} / \mathrm{hr}-{ }^{\circ} \mathrm{F}$ and then with a $20 \%$-reduced UA of $307 \mathrm{Btu} / \mathrm{hr}-{ }^{\circ} \mathrm{F}$. The difference in average indoor air temperatures was compared for three distinct thermostat set point control strategies. The strategies used were a constant $70.5^{\circ} \mathrm{F}$, a single-evening setback to $60^{\circ} \mathrm{F}$ from $70.5^{\circ} \mathrm{F}$, and a double setback, morning and evening, to $60^{\circ} \mathrm{F}$ from $70.5^{\circ} \mathrm{F}$.

The heating system used in the simulation was electric resistance heat with no air conditioning. The simulator generated hourly inside temperature data from September through May. The averaged results are presented in Table 4.5. Note the interplay of the two separate effects from Table 4.5. There is the expected effect of the average temperature decreasing as the more dramatic setback activity takes place. Also, as UA decreases, the mean inside air temperature increases. Part of this increase is because of the effect of the heating season shoulder months appearing in the data. During these months, space heating equipment is used very little, and the inside air temperature is often floating above the set point as evidenced by the average temperatures exceeding the set point in the constant-set point scenario. No air conditioning or venting was used in the simulation runs. The lower-UA home loses heat from the inside air in the living space to the outside more slowly. The other part of the UA-related effect is that during the periods of setback, the temperature of the inside air for the lower-UA homes is decaying more slowly than that for the higher-UA home. 
TA8LE 4.5. Mean Simulated Inside Air Temperatures (September through May) for Two Homes and Three Thermostat Control Strategies

\section{Control Strateqies}

Constant thermostat set point Single-evening setback Morning and evening setbacks
$\underline{U A}=385 \underline{U A}=307$

72.3

69.3

67.3
72.7

69.9

68.2

It is clear from these simple simulations that modifying a building's UA can increase its average heating season temperature by at least as much as was observed in the HRCP homes. This is true even for the constant-set point thermostat strategy but is more pronounced when some setback behavior is evident. The hypothesis that thermostat takeback is partially responsible for the lower-than-expected savings in the Hood River project is not supported by the data.

\subsection{COMPARISON TO THE ELCAP HOMES}

Bonneville has also funded a collection of end-use metered data, through ELCAP, for a large group of homes throughout the Northwest region. Previous analyses of the ELCAP Base sample ${ }^{(b)}$ and ELCAP Residential Standards Demonstration Program (RSDP) sample (Drost et al. 1987) use the same methodology as the Hood River end-use metered thermal characterization and invite performance comparisons between the ELCAP samples and Hood River homes.

The mean annual space heating estimates shown in Table 4.6 are for the ELCAP-monitored homes that participated in the RSDP and for the ELCAP base homes. The Model Conservation Standards (MCS) homes are those homes built to aggressive building standards proposed by the Northwest Power Planning Council. The control homes are those built to represent current construction practices of new homes as part of the RSDP. The base homes are roughly representative of the existing single-family, owner-occupied, electrically heated homes in the region. The electrical space heating consumption estimates for the ELCAP homes located in regions having less than 6000 base

(b) 1990 draft report, Pacific Northwest Laboratory, Richland, Washington. 
65 HDD were computed using Seattle TMY data and the occupants' average measured inside temperatures. Seattle TMY data was selected because those AEC's were readily available.

Table 4.6 displays Hood River pre-retrofit consumption for the singlefamily sample as $6.94 \mathrm{kWh} / \mathrm{ft}^{2}-\mathrm{yr}$. This level is fairly close to that of the ELCAP base sample. Post-retrofit end-use metered Hood River consumption for the single-family sample is closest to that of the control homes. If the mean post-retrofit consumption estimate for the single-family homes $(4.81 \mathrm{kWh} /$ $\mathrm{ft}^{2}-\mathrm{yr}$ ) is compared to that of the ELCAP control homes (4.76 kWh/ft2-yr), the Hood River retrofits can be viewed as bringing the homes up to current construction practice on the average.

TABLE 4.6. ELCAP and Hood River Homes' AEC Using Seattle TMY Weather Data

$\begin{array}{cccccc}\text { AEC } & \text { MCS } & \begin{array}{c}\text { ELCAP } \\ \text { Control }\end{array} & \text { Base } & \begin{array}{c}\text { Hood River } \\ \text { Pre-retrofit }\end{array} & \begin{array}{c}\text { Single-Family } \\ \text { Post-retrofit }\end{array} \\ \text { kWh } \mathrm{ft}^{2}-\mathrm{yr} & 3.32 & 4.76 & 7.41 & 6.94 & 4.81\end{array}$





\subsection{WOOD STOVE USAGE}

About $60 \%$ of the end-use metered homes are not included in the thermal performance characterizarions cited in Section 4.0. The predominant reason for excluding these homes is that burning wood creates a significant nonelectric source of space heating energy. 8ecause this analysis excludes days of wood burning, there are not enough days free from the effects of wood burning available to characterize the heating requirements for these excluded sites. (Only 14\% of the homes with wood-stove sensors are included in the previously stated results. For these homes, days with wood-stove usage are excluded prior to the thermal characterizations.) However, the wood-burning homes did provide a way to estimate the amount of expected HRCP savings not realized because of electric heat displacement by the alternate fuel. It is reasonable to expect that subsequent to the retrofits, less burning of wood would be required to heat these homes. Indeed, post-retrofit wood-use surveys indicated that HRCP homeowners reduced wood consumption by an average 0.4 chords between the pre- and post-retrofit winters (Hirst 1987).

For the homes with functional wood-stove sensors a very simple analysis was performed to answer three questions:

1. Did the total number of days of wood-stove usage decrease postretrofit?

2. Did the total number of days of heating system usage increase postretrofit?

3. Did the intensity of wood-stove usage, as represented by the total number of hours the stove was used or the average amount of heat output by the stoves, decrease post-retrofit?

The magnitude of the Hood River wood-stove signal is proportional to the heat output. For each single-family home with a reliable wood-stove sensor having data for at least $90 \%$ of the November-through-March period of 1984 through 1985 and 1985 through 1986 (a total of 43 homes) a mean daily woodstove signal was created by averaging each of the 15-min records for the day. These months are selected to eliminate weatherization installation activities, to pick up the period of heaviest potential wood use, and to minimize missing data for the greatest number of sites. Additionally, little difference is noted in mean outdoor air temperature for the two 5 -month periods. The total 
number of days during which the wood stove is in use during the 5-month period is counted for each site. Those numbers are then averaged for all sites for each heating season. The total number of days during which the electric heating system equipment is in use is also counted for each site. These numbers are then averaged for all sites. These means can be found in Table 5.1 .

The means in Table 5.1 indicate very little change in the number of days when the wood stove was used before and after weatherization measures were installed. There is a slight decrease $(6 \%)$ in the mean total number of days that the wood stove was used. Mean pre- and post-retrofit heater usage are the same. The average wood-stove signal over the November through March period is presented in Table 5.1. The mean heater load over the same period is also shown. Wood-stove usage drops $27 \%$ in the post-retrofit period in the sample mean. While it is conceivable that some of this reduction could be caused by wood-stove sensors becoming dirty with time or failing for other reasons, the magnitude of the change makes this explanation unlikely. The reduction is consistent with the occupant survey results and is further supported by the wood-burning intensity tests described below. The mean heater load drops only $17 \%$.

To address the third question, on wood-burning intensity changes, the mean wood-stove signal for each day in the heating season is binned according to the magnitude of the signal. Hence, each site has a certain number of days in wood-burning categories denoted as low, medium, medium high, and high. Averages for each of these categories are taken for all sites and are summarized in Table 5.2 .

TABLE 5.1. Hood River Single-Family Wood-Stove Usage Summary for 43 Homes--No Weather Normalization (November through March)

\begin{tabular}{|c|c|c|c|c|}
\hline Intensity & $\begin{array}{l}\text { Wood Stove } \\
\text { Mean Days } \\
\text { in Use } \\
\end{array}$ & $\begin{array}{l}\text { Space Heat } \\
\text { Mean Days } \\
\text { in Use } \\
\end{array}$ & $\begin{array}{c}\text { Mean } \\
\text { Wood-Stove } \\
\text { Signal } \\
\end{array}$ & $\begin{array}{l}\text { Mean Space } \\
\text { Heat Load, } \\
\text { kWh/day } \\
\end{array}$ \\
\hline Pre-retrofit & 127 & 51 & 1640 & 25.8 \\
\hline Post-retrofit & 120 & 51 & 1202 & 21.4 \\
\hline Change, \% & -6 & 0 & -27 & -17 \\
\hline
\end{tabular}


IABLE 5.2. Mean Number of Days in Each Burn Category for 43 Single-Family Homes

Intensity

Pre-retrofit

Post-retrofit

Change, $\%$
Burn Category

Low Medium Medium-High High

17

22

39

48

24

23

37

32

$+41$

$+5$

$-5$

$-33$

Figure 5.1 displays the information found in Table 5.2 in graphical

form. These pie charts dramatically demonstrate a decrease in the mean number of days associated with the greatest wood-stove usage in the post-retrofit period as compared to the pre-retrofit period.

For the 43 single-family homes analyzed, the wood-stove usage did appear to drop by $27 \%$ after the installation of weatherization measures. The heater usage also went down but about 14\%. For this group of homes, it appears that the greatest savings was seen in reduced wood-stove usage, although a significant reduction in space heating was also observed. The total number of days during which the wood stove was used dropped about $6 \%$ post-retrofit, and the total number of days during which the heater was used stayed about the same.

\section{Pre-Retrofit Burn Intensity}

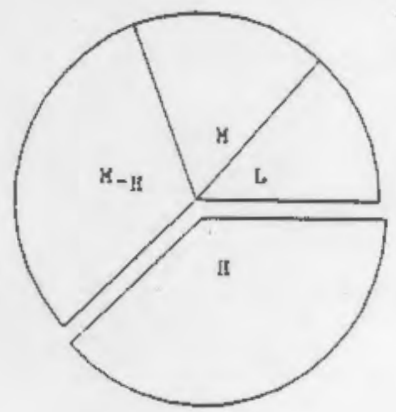

Mean Days for Each Catesory
Post-Retrofit Burn Intensity

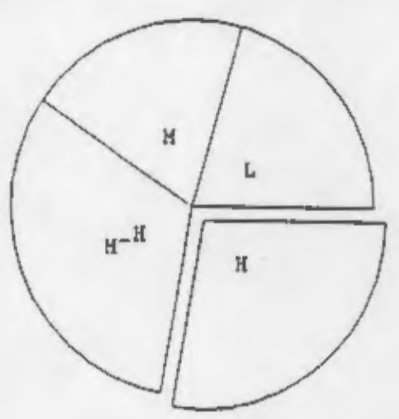

Mean Days for Each Category

FIGURE 5.1. Pre- and Post-Retrofit Mean Shares of Total Days for Each of Four Burning-Intensity Categories for 43 Single-Family Homes During the November I Through March 31 Period 
In the context of the HRCP savings estimates, which are based on an assumption of no wood-stove use, the reduction in post-retrofit wood-stove use is a type of takeback, in that occupants "diverted" some of the savings away from reduced electric bills. However, an analysis of the ELCAP wood-burning homes (Le Baron 1988) suggests that at least part of the disproportionate reduction in wood-stove use is unintentional on the part of the occupants. Le Baron showed that wood use is most intense in the evening hours, which are relatively warm compared to the night and early morning hours. Increased insulation in the post-retrofit HRCP homes could slow indoor temperature decay such that wood heating is simply not required until much later when occupants are sleeping and the electric heating system must meet the heating demand. 


\subsection{MISSING SAVINGS}

Our analyses of the HRCP end-use metered homes show actual retrofit savings considerably lower than those projected at the inception of the project. This finding is consistent with that of Hirst (1987). Of the anticipated $6100 \mathrm{kWh} / \mathrm{yr}$ total savings per house, Hirst observed achieved savings of only $43 \%$. Hirst postulates a number of potential reasons for the discrepancy. In this section, we discuss Hirst's hypotheses in the context of our analyses. Where appropriate, we examine some of these issues in more detail or provide additional complementary or contrasting theories.

Note that many of the comparisons in this section are based on estimated, not measured, energy consumption values. We have taken the liberty of approximating values that were not originally calculated in our analyses or those of Hirst (1987) to make the comparisons more meaningful.

\subsection{COMPARISON OF OUR RESULTS}

A comparison of our results with those of Hirst (1987) is complicated by the fact that the savings estimates produced in the two reports only overlap for two classes of building among the six classes implicitly defined, as shown in Table 6.1. Further, audit projections of retrofit savings are only

TABLE 6.1. Building Classes Analyzed in Two Hood River Studies

\begin{tabular}{|c|c|c|c|c|c|}
\hline \multirow[b]{2}{*}{ Building Class. } & \multirow[b]{2}{*}{ Building Type } & \multirow[b]{2}{*}{ Fuels } & \multicolumn{2}{|c|}{$\begin{array}{c}\text { Results } \\
\text { Available? }\end{array}$} & \multirow{2}{*}{$\begin{array}{l}\text { Audit } \\
\text { Projected } \\
\text { Savings? } \\
\end{array}$} \\
\hline & & & Hirst & Ours & \\
\hline $\begin{array}{l}\text { All buildings } \\
\text { Electric buildings } \\
\text { Wood buildings }\end{array}$ & $\begin{array}{l}\text { A11 homes } \\
\text { A11 homes } \\
\text { A11 homes }\end{array}$ & $\begin{array}{l}\text { All } \\
\text { Electric } \\
\text { Wood }\end{array}$ & $\begin{array}{l}\text { Yes } \\
\text { Yes } \\
\text { No }\end{array}$ & $\begin{array}{l}\text { No } \\
\text { Yes } \\
\text { No }\end{array}$ & $\begin{array}{l}\text { Yes } \\
\text { No } \\
\text { No }\end{array}$ \\
\hline $\begin{array}{l}\text { Al1 SFDs (a) } \\
\text { Electric SFDs } \\
\text { Wood SFOs }\end{array}$ & $\begin{array}{l}\text { Single Family } \\
\text { Single Family } \\
\text { Single Family }\end{array}$ & $\begin{array}{l}\text { All } \\
\text { Electric } \\
\text { Wood }\end{array}$ & $\begin{array}{l}\text { Yes } \\
\text { Yes } \\
\text { No }\end{array}$ & $\begin{array}{l}\text { No } \\
\text { Yes } \\
\text { Yes }\end{array}$ & ${ }_{0}^{\text {No }}$ \\
\hline
\end{tabular}
(a) Single-family detached homes.
(b) Data were not weather normalized. 
readily available for one class, the entire Hood River housing population that received retrofits, which is not one of the two classes common to both analyses.

This lack of overlap occurs because of the nature of the analytical techniques used. The Princeton Scorekeeping Method (PRISM) billing data analysis technique used by Hirst to obtain space heating estimates can only be expected to yield accurate results when the actual total space heating fue 1 consumption is reflected in the billings (as wood is not). Sites that exhibited a high degree of scatter were presumed by Hirst to be wood burning and results were not presented for these homes, although estimates are provided for the populations using both fuels (single-family or all housing types).

The techniques we use to examine heating savings explicitly remove woodburning days to develop savings estimates as if each home was heated purely by electricity. Only homes with very heavy wood burning or other random behavior that precludes characterizing dajly loads with indoor and outdoor temperatures are excluded from the analysis. This is essentially the same criterion used by Hirst, except at the daily instead of monthly level. Applying the filter at the daily level allowed us to eliminate fewer homes from the analysis. We performed a separate analysis of electrical consumption by heavy wood-burning single-family homes. This wood use analysis was not weather normalized, but the two weather years analyzed were quite similar to one another.

\subsubsection{Methodology for Comparison}

Because of the lack of overlap between our study and Hirst's, we have estimated values for the building classes not common to the two reports. In Hirst's work, we estimate values for the two classes of wood-burning homes by applying appropriate proportions to the total data population given in his report. For example, Hirst shows that there were 2362 total homes in the study and 615 electric homes; therefore, there must be 1747 wood-burning homes. Hirst shows that the 2,362 homes use an average $18,600 \mathrm{kWh} / \mathrm{yr}$, while the electric homes use $21,000 \mathrm{kWh} / \mathrm{yr}$. We calculated that the wood-burning homes must average $17,755 \mathrm{kWh} / \mathrm{yr}$ to be consistent with these values. 
Because this section is merely a discussion of the missing savings issues, we have done no additional analyses of the end-use metered homes. Therefore, a similar estimation process was applied to fill some of the gaps in our results. In this case, we combined the average consumption of electric SFD homes with the average consumption of wood-burning SFDs to obtain total SFD population consumption estimates. In doing so, we use Hirst's ratio of the number of electric SFDs to the number of wood-burning SFDs because he analyzed a larger, more representative sample of homes. By assuming that the ratio between electric consumption and wood-burning consumption for other (non-SFD) homes is identical to that of SFD homes, we estimated electrical consumption for all classes of wood-burning homes. Finally, using Hirst's electric/wood population ratio, we estimate consumption for the entire population.

Table 6.2 displays these various observed and estimated data. Note that our analysis of wood-burning homes' electrical consumption included only the months of November through March. For this comparison, we have scaled these values upward by a factor of 1.34 , the ratio of heating degree days (base $60^{\circ} \mathrm{F}$ ) for the entire year and the November-through-March period for 0lympia, Washington. Among the regional TMY sites, Olympia has the seasonal temperature pattern most like that of Hood River. Obviously, this provides only an approximation of the annual electric loads in these buildings. However, in contrast to the vast differences between predicted and observed savings in the HRCP homes, the errors introduced by this approximation are reasonably small.

The data derived from the Hirst analysis in Table 6.2 show that the electric space heat savings estimates for the wood sites are apparently larger than for the electrically heated sites. This is probably a result of inaccuracies in PRISM estimates for the wood sites, as would be expected given the degree of scatter introduced in monthly billings by wood-burning behavior. Hirst points out that for the All Building and All SFD classes, there is a slightly higher estimated space heating savings than total savings, incorrectly implying that savings taken by hot water measures were negative. This was attributed to inaccuracies in PRISM estimates, so the total savings 
IABLE 6.2. Raw Data and Population Estimates

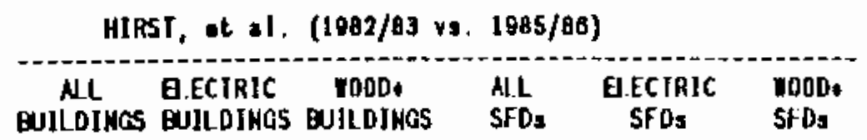

\begin{tabular}{|c|c|c|c|c|c|c|}
\hline $\begin{array}{l}\text { NLWBER IN SAUPLE } \\
\text { FLOOR AREA }\end{array}$ & $\begin{array}{l}2,302 \\
1,360\end{array}$ & $\begin{array}{r}816 \\
1,360\end{array}$ & $\begin{array}{l}1,747 \\
1,316\end{array}$ & $\begin{array}{l}1,615 \\
1,668\end{array}$ & $\begin{array}{r}362 \\
1,678\end{array}$ & $\begin{array}{l}1,183 \\
1,526\end{array}$ \\
\hline $\begin{array}{l}\text { ACE IIEAT, BEFBRE } \\
\text { PACE HEAI, AFTER } \\
\text { ACE HEAI SAYIHCS } \\
\text { CAT SAYINCS, }\end{array}$ & $\begin{array}{l}7,600 \\
4,800 \\
2,708 \\
36 x\end{array}$ & $\begin{array}{l}9,209 \\
0,600 \\
2,600 \\
20 x\end{array}$ & $\begin{array}{l}0,902 \\
4,168 \\
2,135 \\
10 x\end{array}$ & $\begin{array}{r}1,600 \\
1,600 \\
3,600 \\
39 x\end{array}$ & $\begin{array}{r}10,300 \\
7,000 \\
3,300 \\
32 x\end{array}$ & $\begin{array}{r}6,711 \\
3,966 \\
2,968 \\
13 x\end{array}$ \\
\hline $\begin{array}{l}\text { IOTAL, BEFORE } \\
\text { IOIAL, AFIER } \\
\text { IOIAL SAYINCS } \\
\text { TOIAL SAYIHGS, }\end{array}$ & $\begin{array}{r}18,600 \\
18,600 \\
2,600 \\
14 x\end{array}$ & $\begin{array}{r}21,600 \\
17,000 \\
3,200 \\
15 x\end{array}$ & $\begin{array}{r}17,756 \\
15,366 \\
2,369 \\
137\end{array}$ & $\begin{array}{r}20,100 \\
17,508 \\
2,968 \\
145\end{array}$ & $\begin{array}{r}24,100 \\
20,100 \\
4,000 \\
168\end{array}$ & $\begin{array}{r}19,170 \\
18,613 \\
2,663 \\
13 x\end{array}$ \\
\hline
\end{tabular}

(- Indicates Estimated Values for this Building Population)

\begin{tabular}{|c|c|c|c|c|c|}
\hline $\begin{array}{l}\text { AlL. } \\
\text { BILDINGS }\end{array}$ & $\begin{array}{r}\text { BECIRIC } \\
\text { DUILOINGS }\end{array}$ & $\begin{array}{l}\text { node } \\
\text { BuILOINGS }\end{array}$ & \multirow{2}{*}{$\begin{array}{l}\text { ALL: } \\
\text { SFDis } \\
\begin{array}{l}N / A \\
H / A\end{array}\end{array}$} & \multirow{2}{*}{$\begin{array}{r}\text { E ECIRIC } \\
\text { SF Os } \\
\\
1,122 \\
\text { B2 }\end{array}$} & \multirow{2}{*}{ 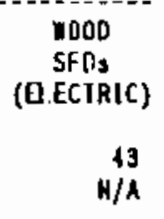 } \\
\hline $\begin{array}{l}N / A \\
K / \Lambda\end{array}$ & $\begin{array}{r}113 \\
1,293\end{array}$ & $H / A$ & & & \\
\hline $\begin{array}{r}0,118 \\
5,317 \\
1,191 \\
17 x\end{array}$ & $\begin{array}{r}18,111 \\
7,679 \\
2,132 \\
211\end{array}$ & $\begin{array}{r}5,119 \\
1,188 \\
633 \\
12 x\end{array}$ & $\begin{array}{r}6,115 \\
5,051 \\
1,361 \\
21 x\end{array}$ & $\begin{array}{r}19,315 \\
7,415 \\
2,900 \\
28 \times\end{array}$ & $\begin{array}{c}6,222 \\
1,331 \\
891 \\
17 x\end{array}$ \\
\hline \multicolumn{4}{|c|}{$\begin{array}{l}\text { OL YUPLA IUY USEO FOR WOOD RIVER IN } \\
\text { ADJUSIING WOOD AMKE. YSIS SEESSOH IO YEAR }\end{array}$} & $\begin{array}{c}y 000 \\
\text { SFDs } \\
(W 000)\end{array}$ & $\begin{array}{l}\text { APPAREHT } \\
\text { WOOD SENSOR } \\
\text { CAL. IERAIJOH }\end{array}$ \\
\hline $\begin{array}{l}\text { DAYS IN NO } \\
\text { DOEO IN ND } \\
\text { DDE IN YE } \\
\text { DDG YH/NO }\end{array}$ & $\begin{aligned} V \cdot V A R & = \\
V-U A R & = \\
A R & = \\
V-Y A R & =\end{aligned}$ & $\begin{array}{r}151 \\
2,732 \\
3,662 \\
1.31\end{array}$ & & $\begin{array}{r}331,939 \\
243,287 \\
89,652 \\
278\end{array}$ & $\begin{array}{l}0.0153 \\
0.127\end{array}$ \\
\hline
\end{tabular}


were used in the analysis of Hirst (1987). However, this implicitly assumes that the savings resulting from the hot water measures were small, a conclusion not supported by the apparent hot water savings (the difference between the space heat savings and total savings for all types of electric homes or the electric SFDs, $600 \mathrm{kWh} / \mathrm{yr}$ and $700 \mathrm{kWh} / \mathrm{yr}$, respectively).

We did not explicitly examine the water heating savings in the enduse metered homes, but there appeared to be sizeable savings in nearly all the homes examined. Our analysis is specifically confined to space heating, restricting the comparison with Hirst to space heating results and derivatives thereof at this time. However, the data do not indicate explicitly whether the comparison is better made using the space heating or total savings estimates from Hirst. We have somewhat arbitrarily chosen to use the space heating savings at this time (note this was not the decision of Hirst). We believe that this is justified for the population of electric homes, the one population that is directly comparable to our results.

\subsubsection{Comparisons of Basic Heating Results}

The estimated heating consumption from the two analyses for each of the six populations are compared side-by-side in Table 6.3. That table simply replicates the heating data from Table 6.2 but in side-by-side fashion to facilitate comparisons.

First, it is important to establish that the populations analyzed by the two studies are relatively similar. The only indicators available are floor area and absolute consumption before and after the retrofits. On the basis of floor area, the only valid points of comparison are for all the electrically heated homes and the electrically heated SFDs. The electric SFDs of our analysis are somewhat smalier (15\%) than those of Hirst. This suggests the possibility of normalizing by floor area, but space heating is more a function of surface area than floor area, so the benefit of doing this is probably marginal. The floor areas of all types of electrically heated homes are seen to be remarkably comparable, differing by only $5 \%$. 
IABLE 6.3. Comparison of Savings Estimates Based on Metered Data and Fue B Bill Analysis

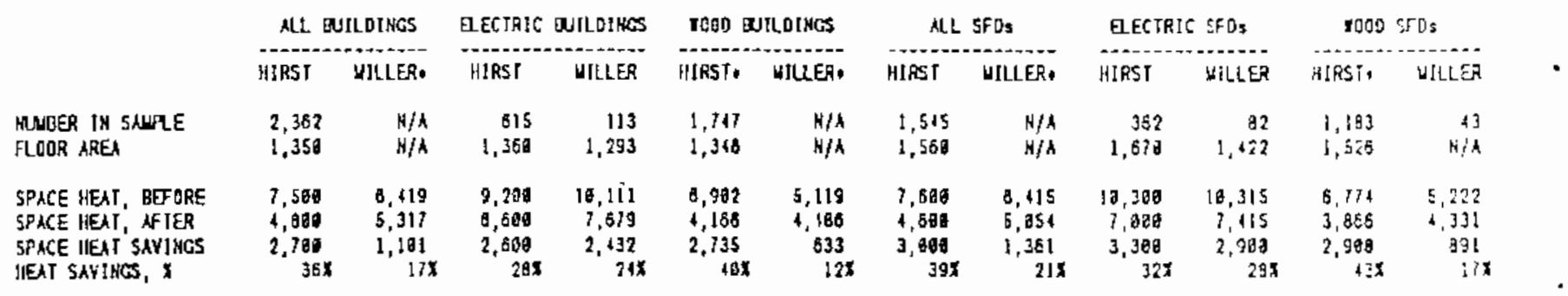

(* Indicates Estioated Vilues for this Euilding Population)

Both the space heating consumption and the savings estimates of these two groups of homes are also very similar. This lends confidence to the conclusion that the two analyses were conducted using essentially comparable groups of homes. In each case the savings estimates agree to within $12 \%$ (fractional savings of $28 \%$ to $24 \%$ and $32 \%$ to $28 \%$ of space heat for all electric homes and electric SFDs, respectively). Thus, the basic conclusions of the two analyses regarding space heat savings for the population of electrically heated homes are mutually supportive.

The results in Table 6.3 are not as encouraging for the other four building classes, however. The basic problem is the difference in estimates for the wood-burning population, where the savings indicated by Hirst are dramatically larger than ours. This difference carries through into the population estimates for the SFDs and all homes. Note that this difference is greatly reduced if the total savings estimates from Hirst are used and 600 to $700 \mathrm{kWh} / \mathrm{yr}$ of savings are subtracted for the hot water retrofits, yet a difference of over $100 \%$ would still remain. This indicates that substantial insight could be gained by a detailed analysis of all the end-use metered wood-burning homes (those we didn't analyze using the AEC characterizations), matching the classification scheme of Hirst, to refine our wood-burning population estimates. 


\subsubsection{Comparison of Heating Results Modified to Account for Wood Burning}

The issue of displacement by wood burning in Hood River appears to be major, as indicated by both our work and Hirst's. The data in Table 6.3 can be used to estimate displacement by wood and combined with electrical space heat, to estimate a total space heating load that should be more comparable with the load estimated by the original audits. This is displayed in Table 6.4. Note that the data for the electrically heated homes remains unchanged, but we assume that the wood-burning homes use the same quantity of space heat as the electric homes, yet use it from two sources. In this fashion, estimates of the contribution of wood to the total space heating load are developed for the other classes of homes both before and after the retrofits.

Note that the row labelled "Total Savings $\%$ " in Table 6.4 refers to savings as a percentage of the pre-retrofit total heating estimate. We use fractional savings rather than absolute savings in the comparisons to minimize differences resulting from differing baseline assumptions. Percentages also facilitate better comparisons with the original audit savings estimates because the pre- and post-retrofit consumption projections are not included in the Hood River audit database; only the differences between the two (the savings) were retained.

Note that the savings in wood estimated from Hirst's data are actually negative for the three All Buildings classes, and much smaller than our estimates for SFDs (see Table 6.2). By examining the basic data in Table 6.2, this savings is seen to result from the higher savings for the wood-burning buildings than the electric buildings. This is contradictory to the observed takeback effect in wood-burning behavior, and would no longer hold if the savings estimated from Hirst's data were based on the total electric bills instead of PRISM space heating estimates as discussed previously (Section 6.1). The adjustment for hot water savings then becomes critical, however.

The predicted and actual savings adjusted for wood displacement can now be compared. At this point, the six building type classes in Table 6.4 become redundant so only the two classes of interest (All Buildings and Electric 
IABLE 6,4. Adjusted Savings Estimates Based on Analysis of Metered and Billing Data

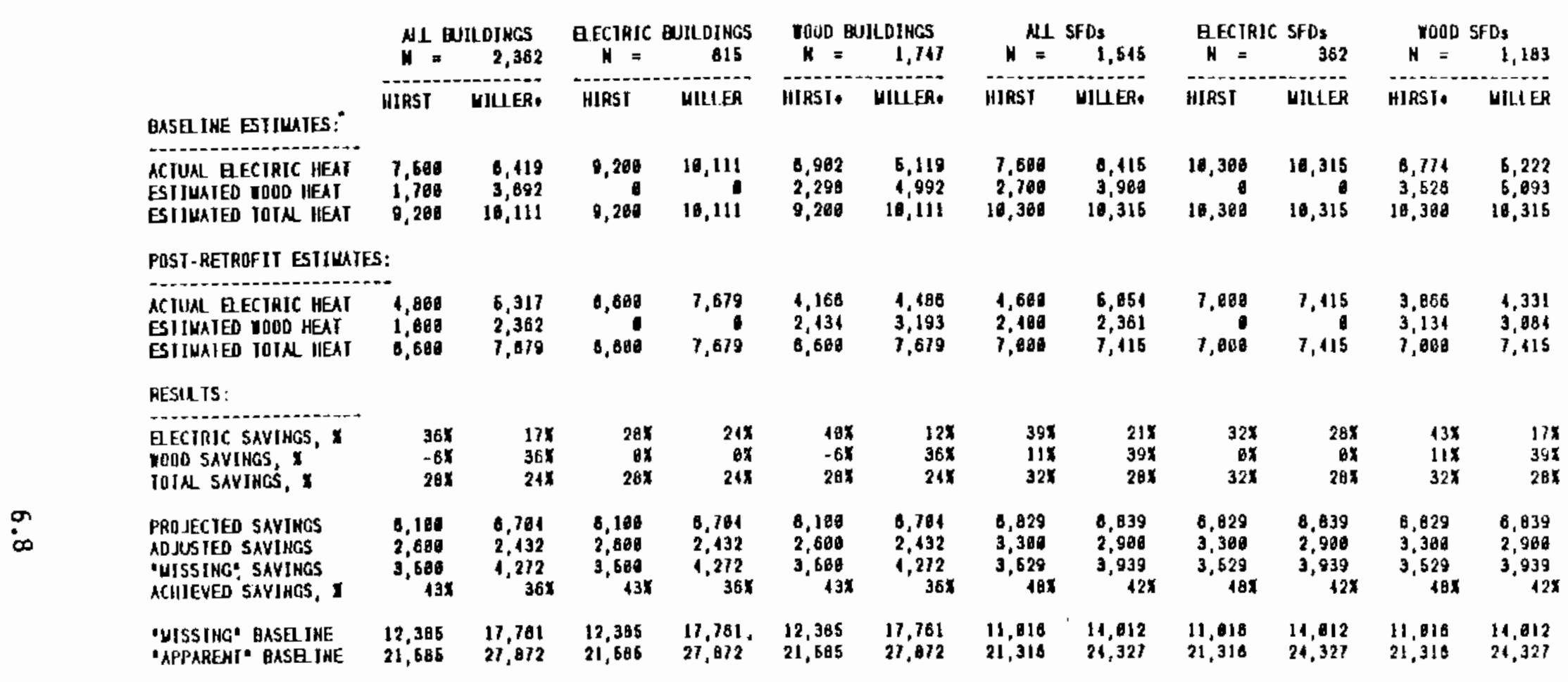

(. Indicates Estiasted Valuos for this Buitding Papulation) 
SFDs) are displayed in Table 6.5 for clarity. The original audit projection of savings for each home in the All Buildings class is $6100 \mathrm{kWh} / \mathrm{yr}$. This estimate corresponds to the data in the first column of Table 6.5. The other three columns represent subsamples that do not correspond directly to the sample on which the $6100 \mathrm{kWh} / \mathrm{yr}$ projection is based. Therefore, we adjust the projected savings in each of those columns by the ratio between its estimated total pre-retrofit heating consumption and the savings in column one.

\section{TABLE 6.5. SUmmary of Adjusted Savings Estimates Based on Metered and Billing Data}

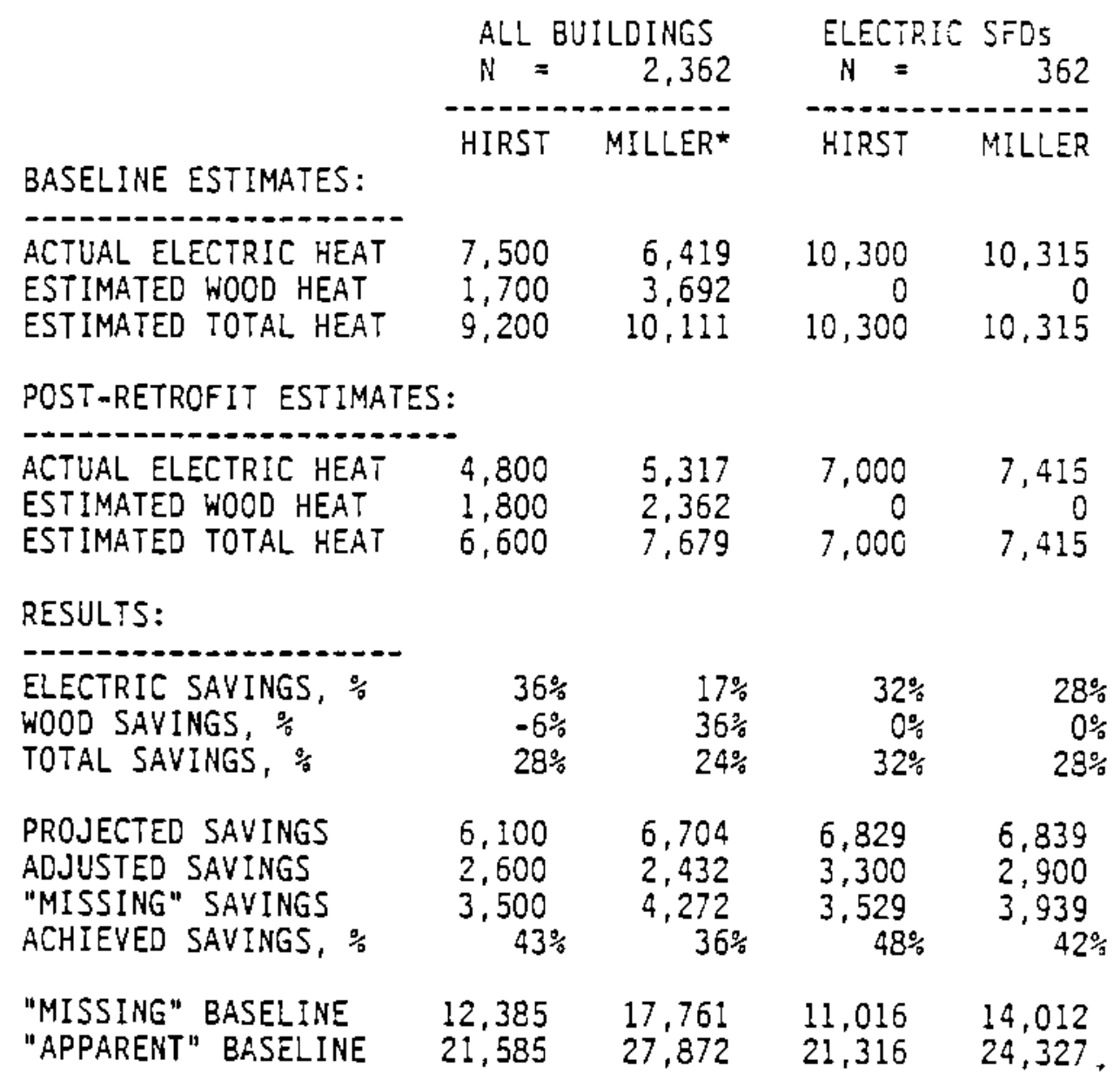


The Adjusted Savings is the combined estimate of electric and wood savings for the class, and the Achieved Savings is the percentage of projected savings as indicated. For the population as a whole, Hirst's data show an achieved fraction of projected savings of $43 \%$. Similarly, our data indicate a $36 \%$ fraction. For electric SFDs, our achieved fraction of projected savings is $48 \%$ compared to Hirst's $42 \%$. Therefore, after accounting for wood use, both studies indicate that more than one-half the projected savings were not achieved. Incorporating accurate hot water savings estimates might raise the achieved percentages, but Hirst's analyses indicate that the adjustments would be small.

\subsection{HYPOTHESES REGARDING THE MISSING SAVINGS}

The overall population average savings estimate based on energy audits of each HRCP site was $6100 \mathrm{kWh} / \mathrm{yr}$. Even for the electrically heated sites, where both studies agree closely and savings would be expected to be highest, less than half of the expected savings were actually achieved. There are several basic conclusions and/or hypotheses drawn by Hirst (1987) regarding why the expected savings were not achieved. These can be summarized as follows:

- typical discrepancies between predicted and achieved savings

- reduced pre-retrofit baseline energy consumption

- post-retrofit increases in thermostat settings

- disproportionately larger post-retrofit decreases in use of wood for heating. 
The first conclusion, that there are typically unrealized savings from retrofit programs, is undoubtedly true. However, this observation is central to the research questions that the HRCP was designed to answer and demands further examination and explanation.

Low pre-retrofit consumption was concluded to be the major contributor to the low achieved savings. Because the actual pre-retrofit heating load was dramatically below expectations, actual savings might be expected to be proportionally lower than predicted. Hirst states that pre-retrofit energy consumption in the Hood River SFDs was about 20,400 kwh/yr; $7600 \mathrm{kwh} / \mathrm{yr}$ of which was because of heating. He cites the typical regional average total consumption at about $25,000 \mathrm{kwh} / \mathrm{yr}$ with $13,000 \mathrm{kwh} / \mathrm{yr}$ for heating. The low HRCP consumption relative to the regional average was concluded to result from recent increases in local fuel prices, a recent local economic downturn, and participation by residents in other conservation programs.

However, the energy consumption observed in the ELCAP residences suggests that Hirst's region-wide consumption estimate of $25,000 \mathrm{kWh} / \mathrm{yr}$ is too high. The ELCAP homes in the same climate zone as Hood River averaged 21,800 $\mathrm{kWh} / \mathrm{yr}$ total consumption, 8100 of which was used for heating. These observed consumption levels, while higher than the actual HRCP pre-retrofit levels, are not as dramatically different as Hirst's data suggest. Unfortunately, the pre-retrofit energy consumption predicted by the HRCP audits cannot be compared with these numbers because they were not retained in the audit database. Nonetheless, there is evidence that part of the missing savings are attributable to misestimation of baseline loads.

Hirst's last two conclusions, regarding higher post-retrofit indoor temperatures and lower post-retrofit wood use, were discussed in previous sections. While there was an increase in post-retrofit indoor temperatures, we have shown it to be within the range expected as a result of increased thermal integrity of the homes. There is insufficient evidence to conclude that occupants knowingly raised their thermostat set points. At any rate, Hirst's estimate of the savings attributable to temperature takeback was smal1--300 kwh/yr. 
The conclusion that some of the retrofit savings were taken in reduced wood use is confirmed by our analyses, which show that twice as much savings went toward reductions in wood use as went toward reductions in electricity. Indeed, after accounting for wood use, our analyses still show an achieved savings fraction of around $40 \%$.

\subsubsection{Hypotheses Regarding Misestimation of Basel ine Loads}

There are four fundamental reasons why baseline space heat consumption (and savings) might be overpredicted by audits based on Bonneville's Standard Heat Loss Methodology (SHLM):

- The audits do not account for displacement by wood burning.

- The audits implicitiy assume a room temperature and thermostat strategy.

- The audits implicitly assume a level and utilizability of internal heat gains (e.g., from lights and plug loads).

- The audits implicitly assume a level of room closures and/or zoned heating systems.

We have already addressed the first two reasons. The third, regarding internal and solar gain levels, relates to the " $C$-factor," a simple degreeday multiplier in the SHLM. The $\mathrm{C}$-factor adjusts standard (base-65 ${ }^{\circ} \mathrm{F}$ ) degree days to account for nominal assumptions about internal and solar heat gains, thermostat settings, and setback behavior. Poor assumptions regarding nonHVAC heat gains could result in an overprediction of savings, but the $C$ factor would have to be incorrect by a factor of two to account for the missing savings. It is unlikely that the effective number of degree days was miscalculated that badly. The remaining issue is zoning.

In the absence of room-by-room temperature data it is not possible to confidently estimate the prevalence and magnitude of zoning in the HRCP homes. However, to provide a context for discussion, we have examined the potential magnitude of zoning effects on a purely theoretical basis. We define a reasonable house geometry (see Figure 6.1) and vary its size (see Table 6.6), insulation levels (see Table 6.7), and zoning strategy (see Table 6.8). For each combination, we compute the effective reduction in envelope conductance 

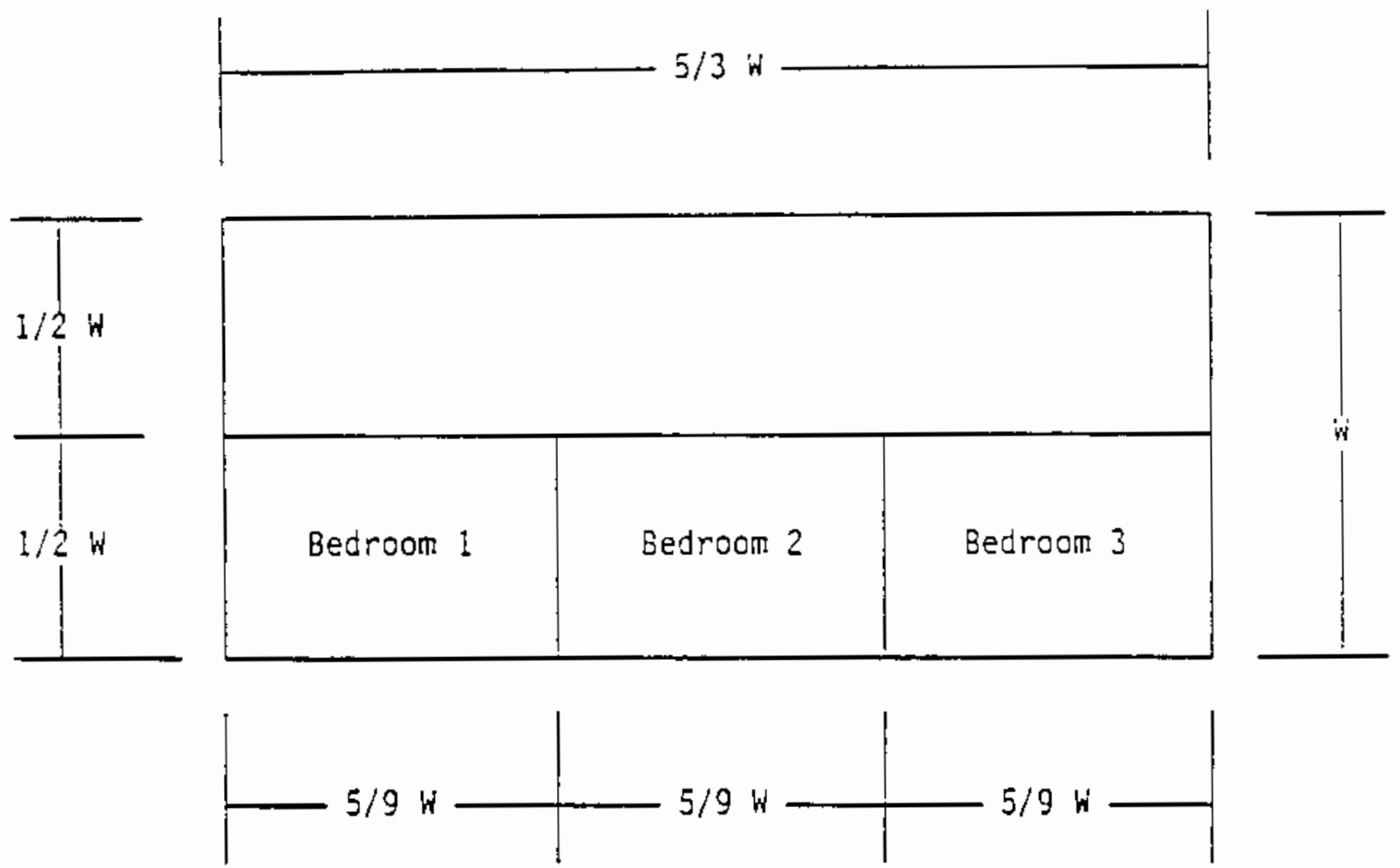

\section{FIGURE 6.1. House Geometry}

TABLE 6.6. House Dimensions

Width, ft

Length, ft

Floor Area, sqft

Height, ft

Volume, cuft

Windows, $\%$ floor

Doors, sqft

Net Wall, sqft

\begin{tabular}{ccccc}
\multicolumn{5}{c}{ Design } \\
\hline 1 & 2 & 3 & 4 & 5 \\
25 & 30 & 35 & 40 & 45 \\
42 & 50 & 58 & 67 & 75 \\
1042 & 1500 & 2042 & 2667 & 3375 \\
8 & 8 & 8 & 8 & 8 \\
8333 & 12000 & 16333 & 21333 & 27000 \\
$10 \%$ & $10 \%$ & $10 \%$ & $10 \%$ & $10 \%$ \\
120 & 120 & 180 & 180 & 240 \\
843 & 1010 & 1109 & 1260 & 1343
\end{tabular}


TABLE 6.7. House Construction

Component

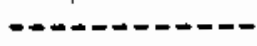

Walls

Windows

Ceiling

Infiltration

Fioor

Doors

Partitions

\begin{tabular}{|c|c|c|c|c|}
\hline I & 2 & 3 & 4 & 5 \\
\hline 4.0 & 11.0 & 19.0 & 19.0 & 26.0 \\
\hline 1.0 & 1.0 & 2.0 & 2.0 & 3.0 \\
\hline 4.0 & 19.0 & 30.0 & 38.0 & 50.0 \\
\hline 1.0 & 1.0 & 0.4 & 0.4 & 0.2 \\
\hline 4.0 & 11.0 & 19.0 & 24.0 & 38.0 \\
\hline 1.5 & 1.5 & 2.5 & 4.0 & 7.0 \\
\hline 3.0 & 3. & 3.0 & 3.0 & 3.0 \\
\hline
\end{tabular}

TABLE 6.8. Zoning Strategy

$\begin{array}{lcccc} & \begin{array}{l}\text { Floor } \\ \text { Area } \\ \text { Zoned }\end{array} & \begin{array}{l}\text { Wall } \\ \text { Area } \\ \text { Zoned }\end{array} & \begin{array}{r}\text { Partion } \\ \text { Area } \\ (\% \text { of W) }\end{array} \\ \text { Type } & * & - & & \\ \text { Hone } & 0 & 0 \% & 0 \% & 0 \% \\ \text { Bedroom 1 } & 1 & 17 \% & 20 \% & 106 \% \\ \text { Bedrooms 1 \& } & 2 & 32 \% & 30 \% & 161 \% \\ \text { Bedrooms i-3 } & 3 & 50 \% & 50 \% & 167 \%\end{array}$

(UA) because of the closed-off rooms. (When a room is not heated, its interior walls act as an additional R-value between the thermostat and the outside air.)

The UA calculations, by component, are displayed in Table 6.9. The whole-house UAs are further summarized in Table 6.10 and presented as percentages of the nominal (non-zoned) UAs in Table 6.11. The effect of zoning half the floor space of a house results in UAs that range from $55 \%$ to 83\% of the nominal level in uninsulated and superinsulated houses, respectively. A more modest level of zoning roughly corresponding to closing 
IABLE 6.9. Heat Loss Coefficient Calculation as a Function of Insulation Level, Size, and Zoning Strategy

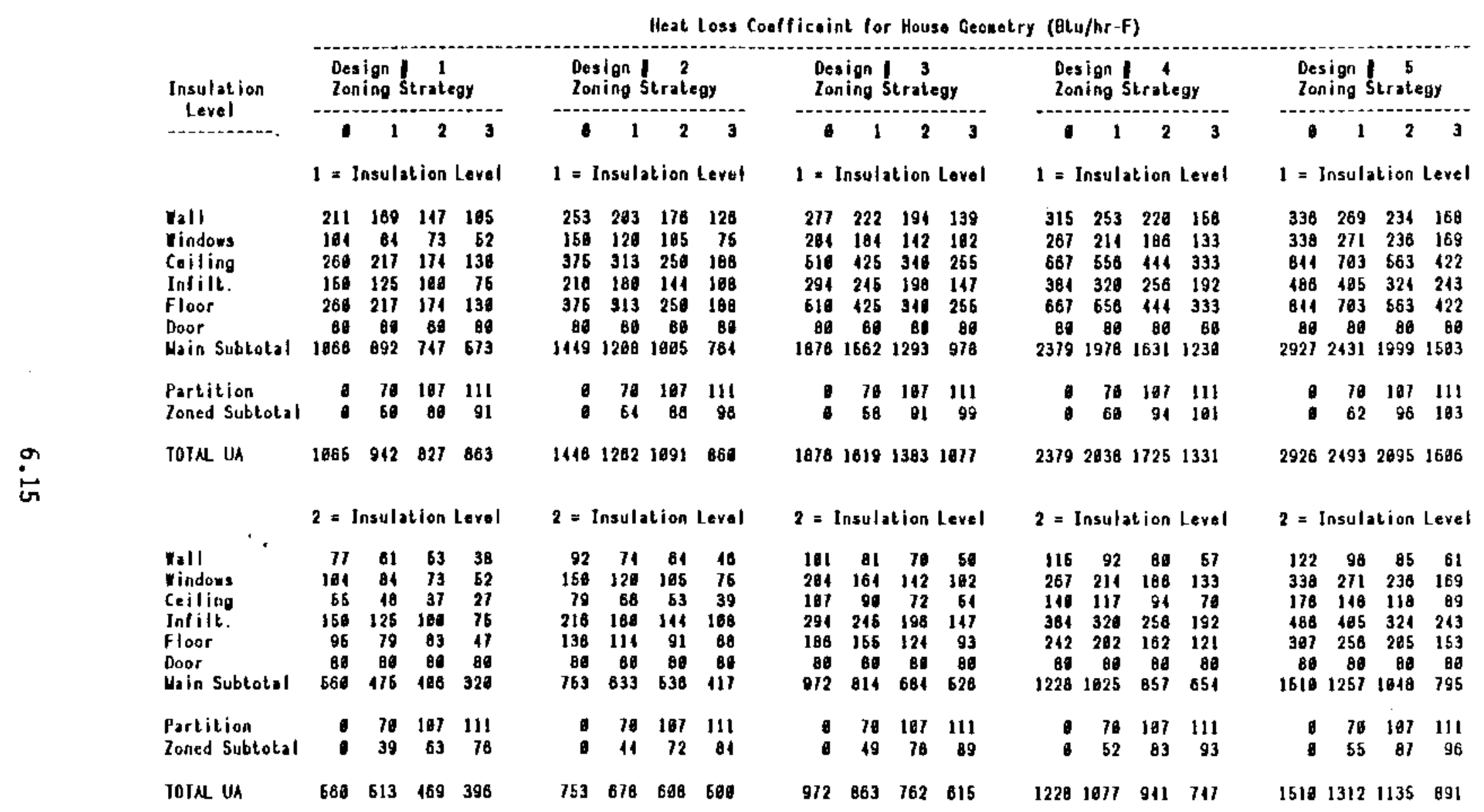


IABLE 6.9. (contd)

Heat Loss Coelficoint for House Geonetry (Btu/hr-F)

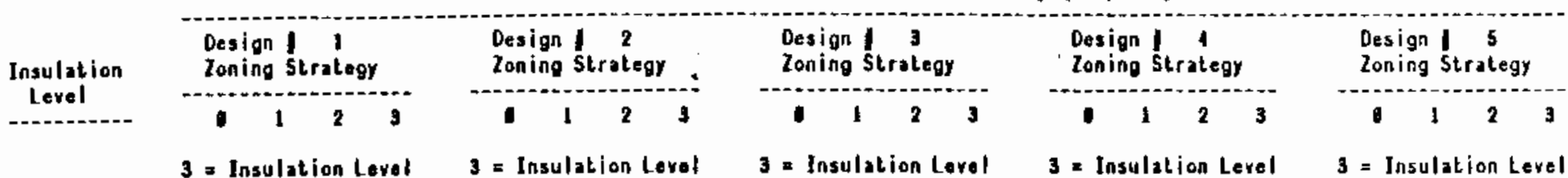

$\begin{array}{lllll}\text { Vall } & 14 & 38 & 31 & 22 \\ \text { vindows } & 62 & 12 & 30 & 28 \\ \text { Ceiling } & 35 & 29 & 23 & 17 \\ \text { Jnfilt. } & 69 & 60 & 19 & 38 \\ \text { Floor } & 56 & 18 & 37 & 21 \\ \text { Door } & 18 & 18 & 48 & 18\end{array}$

$\begin{array}{rrrr}63 & 43 & 37 & 27 \\ 75 & 68 & 52 & 36 \\ 69 & 12 & 33 & 25 \\ 88 & 72 & 69 & 13 \\ 79 & 68 & 53 & 39 \\ 18 & 18 & 18 & 18\end{array}$

$\begin{array}{rrrr}56 & 17 & 11 & 29 \\ 102 & 82 & 71 & 51 \\ 68 & 57 & 15 & 31 \\ 118 & 98 & 78 & 69 \\ 107 & 90 & 72 & 64 \\ 18 & 18 & 18 & 18 \\ 692 & 121 & 355 & 276\end{array}$

$\begin{array}{lllll}y_{a} i n & \text { Subtotal } 294 & 258 & 215 & 171\end{array}$

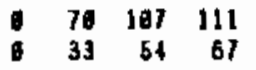

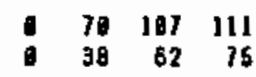
Poned Subtok

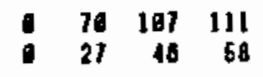

$\begin{array}{llll}392 & 363 & 335 & 297\end{array}$

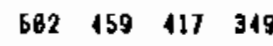

on

TOINL UA

$294 \quad 277 \quad 261 \quad 229$

1. Insutation Levol

1 = Insulation Lerel

$\begin{array}{rrrr}68 & 63 & 18 & 33 \\ 133 & 197 & 93 & 67 \\ 89 & 76 & 59 & 11 \\ 151 & 128 & 182 & 11 \\ 14 & 117 & 94 & 70 \\ 18 & 18 & 18 & 48\end{array}$

$\begin{array}{llll}630 & 621 & 143 & 339\end{array}$

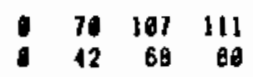

$630569511 \quad 420$

$\begin{array}{llll}71 & 57 & 49 & 35\end{array}$

$\begin{array}{llll}169 & 135 & 118 & 84\end{array}$

113 94 $75 \quad 56$

$194 \quad 162 \quad 130 \quad 97$

$\begin{array}{llll}178 & 149 & 118 & 89\end{array}$

$\begin{array}{llll}18 & 18 & 18 & 18\end{array}$

- $\quad 79 \quad 197 \quad 111$

* $15 \quad 45$

1 = Insulation Lerel $\quad 1$ = Insulation Level

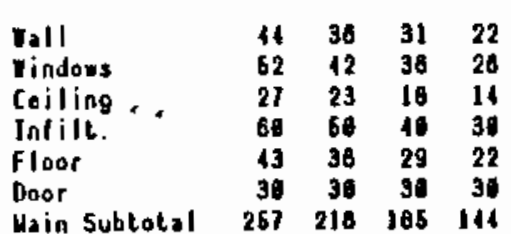

$\begin{array}{rrrr}53 & 13 & 31 & 21 \\ 76 & 60 & 62 & 38 \\ 39 & 33 & 28 & 20 \\ 86 & 72 & 58 & 13 \\ 83 & 52 & 42 & 31 \\ 30 & 38 & 30 & 30 \\ 317 & 290 & 215 & 180\end{array}$

$\begin{array}{llll}68 & 47 & 11 & 29\end{array}$

$\begin{array}{cccc}162 & 82 & 71 & 61 \\ 51 & 45 & 36 & 27\end{array}$

$\begin{array}{rrrr}61 & 15 & 38 & 21 \\ 118 & 98 & 78 & 58\end{array}$

$\begin{array}{llll}85 & 71 & 67 & 13\end{array}$

$\begin{array}{rrrr}39 & 30 & 30 & 38\end{array}$

Wain Subtotal

- $70107 \quad 111$

9 70 187 11!

$\begin{array}{llll}70 & 107 & 111\end{array}$

Partition
loned Subtotal

$257 \quad 212 \quad 228 \quad 290$

$347 \quad 321 \quad 297 \quad 254$

$\begin{array}{llll}117 & 469 & 373 & 311\end{array}$

$\begin{array}{rrrr}88 & 59 & 18 & 33 \\ 133 & 187 & 93 & 67 \\ 10 & 68 & 17 & 35 \\ 161 & 128 & 162 & 77 \\ 111 & 93 & 71 & 68 \\ 30 & 38 & 30 & 39 \\ 665 & 169 & 393 & 297\end{array}$

71070

IDTAL UA

$b=$ Insulation Level

$b=$ Insulation Levol

$6=$ Insulation Level

$\begin{array}{rrr}-70 & 107 & 111 \\ - & 68 & 78\end{array}$

$665 \quad 610 \quad 159 \quad 378$

$\begin{array}{rrrr}71 & 57 & 99 & 35 \\ 169 & 135 & 118 & 81\end{array}$

$89 \quad 71 \quad 59 \quad 11$

$\begin{array}{llll}194 & 152 & 130 & 97\end{array}$

$\begin{array}{rrrr}141 & 117 & 94 & 79 \\ 38 & 38 & 30 & 38\end{array}$

$693 \quad 575 \quad 486362$

6 $70 \quad 107111$

$\begin{array}{llll}693 & 619 & 551 & 115\end{array}$

$\begin{array}{lllll}\text { Yall } & 32 & 28 & 23 & 16 \\ \text { rindows } & 35 & 28 & 21 & 17 \\ \text { Ceiling } & 17 & 14 & 12 & 9 \\ \text { Intilt. } & 39 & 25 & 28 & 15 \\ \text { Floor } & 27 & 23 & 18 & 11 \\ \text { Door } & 17 & 17 & 17 & 17\end{array}$

$\begin{array}{lrrrr}\text { Droor } & 17 & 17 & 17 & 17 \\ \text { Nain Subtolal } & 159 & 133 & 114 & 80\end{array}$

Partition

$\begin{array}{rrrr}0 & 78 & 107 & 111 \\ 8 & 19 & 32 & 43\end{array}$

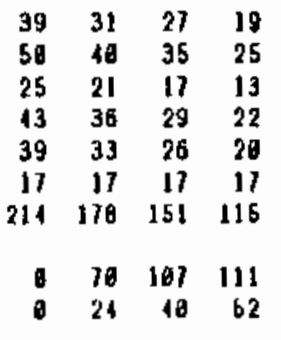

$\begin{array}{llll}43 & 34 & 30 & 21\end{array}$

$\begin{array}{llll}68 & 65 & 47 & 31 \\ 31 & 28 & 23 & 17\end{array}$

$\begin{array}{llll}69 & 49 & 39 & 29\end{array}$

$\begin{array}{llll}64 & 15 & 38 & 27\end{array}$

$\begin{array}{llll}214 & 228 & 192 \quad 148\end{array}$

Lolled juilocal

$\begin{array}{rrrr}9 & 70 & 197 & 111 \\ 6 & 28 & 11 & 68\end{array}$

roik th

$159 \quad 152 \quad 146 \quad 131$

$216 \quad 282 \quad 131 \quad 168$

6 = Insulation Leyel 5 = Insulation Level

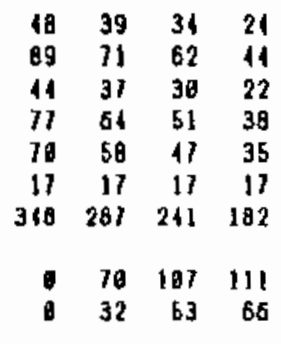

$\begin{array}{llll}310 & 319 \quad 291 \quad 218\end{array}$

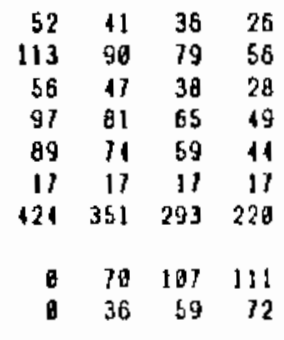

$124 \quad 386 \quad 352 \quad 292$ 
IABLE 6.10. Heat Loss Coefficient as a Function of

Insulation Level, Size, and Zoning Strategy

Heat Loss Coofficeint for House Ceonetry (Btu/hr-F)

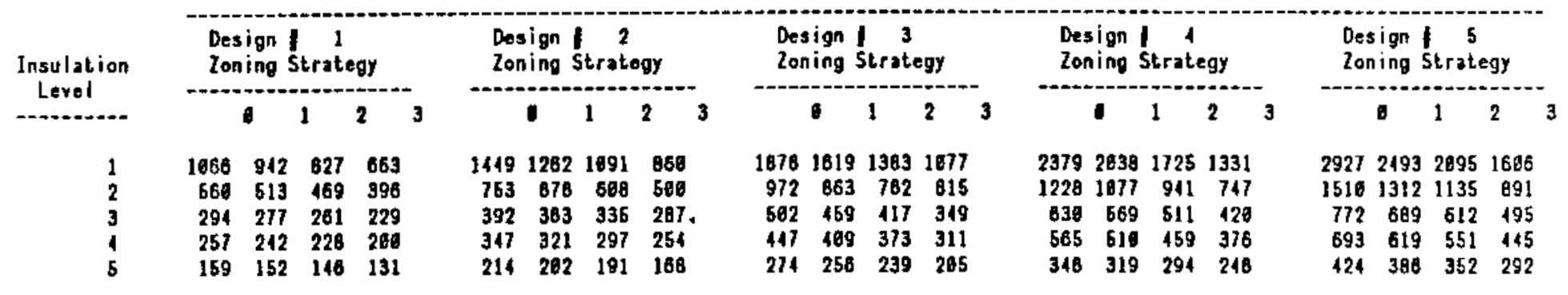

\section{IABLE 6.11. Effect of Zoning Strategy in Reducing} Overall Heat Loss Coefficient

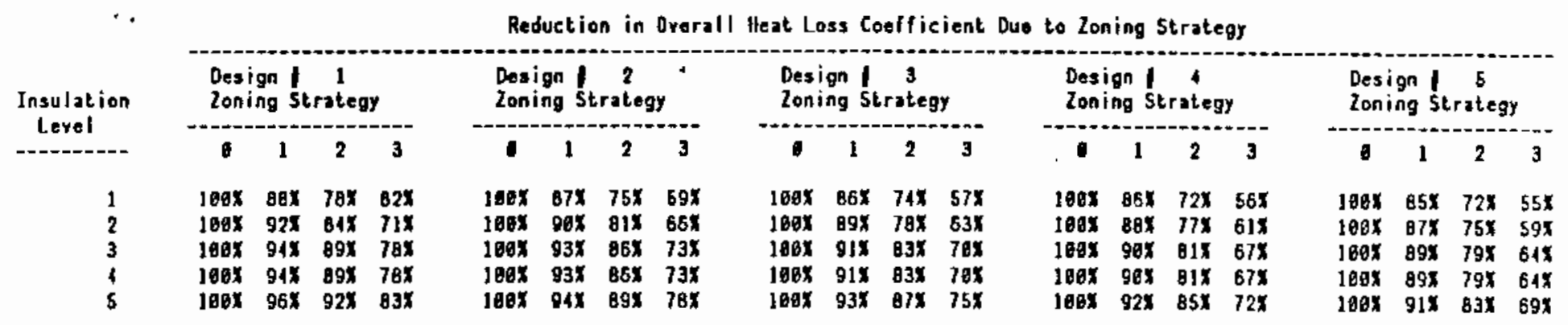


off two bedrooms can result in UA reductions to about $80 \%$ of the nominal value in modestly insulated homes. Note that this roughly corresponds to the difference in nameplate and as-operated UAs observed in ELCAP homes. However, it does seem unlikely that zoning behavior is so predominant as to reduce theoretical baseline space heat consumption by $50 \%$, enough to account for the missing savings.

\subsubsection{Hypotheses Regarding Misestimation of Energy Benefits}

The potential contributors to overpredicted retrofit benefits that have not yet been discussed are zoning and in-situ thermal performance of the retrofit materials. In addition to its effect on baseline loads, zoning has an effect on retrofits that is not widely recognized. The benefit of zoning can be conceptualized as the additional $R$-value provided by the interior partition wall acting in series with the exterior envelope insulation in the zoned part of the house. In an uninsulated (or very poorly insulated) house, the R-value of this partition is about equal to that of the envelope and adds significantly to the effective overall R-value of the zoned rooms. When the envelope is insulated, however, the relative benefit of zoning is decreased because the R-value of the partition wall is small in comparison, and adds only marginally to the overall R-value of the zoned area. It is important to note that this appears just like takeback to an energy analyst--even if the zoning behavior does not change after the retrofit.

Table 6.12 displays the effect of zoning in reducing the actual UA changes caused by a retrofit. For modest levels of zoning, the effect can account for reduced benefits of $30 \%$ in an uninsulated home. The reduction is lower, about $15 \%$ to $20 \%$, for a home with some insulation originally. When combined with the initial error in baseline consumption because of similar levels of zoning, the potential impact on absolute savings rises to the range of $35 \%$ to $50 \%$. If all homes use zoning at this level, the potential magnitude is large enough to account for the majority of the "missing savings" in Hood River. 
The remaining possible explanation for the missing savings involves the in-situ thermal performance of the retrofit materials. These materials are laboratory-tested and have long been the subject of research, so poor installation seems to be a more likely contributor to reduced savings. Despite the quality assurance inspections performed in Hood River, it is possible that field conditions are such that fully effective performance could not be achieved. However, this hypothesis is difficult to defend (or refute) with the available data.

TABLE 6.12. Reduction in Retrofit Benefits as a Result of Zoning Strategy

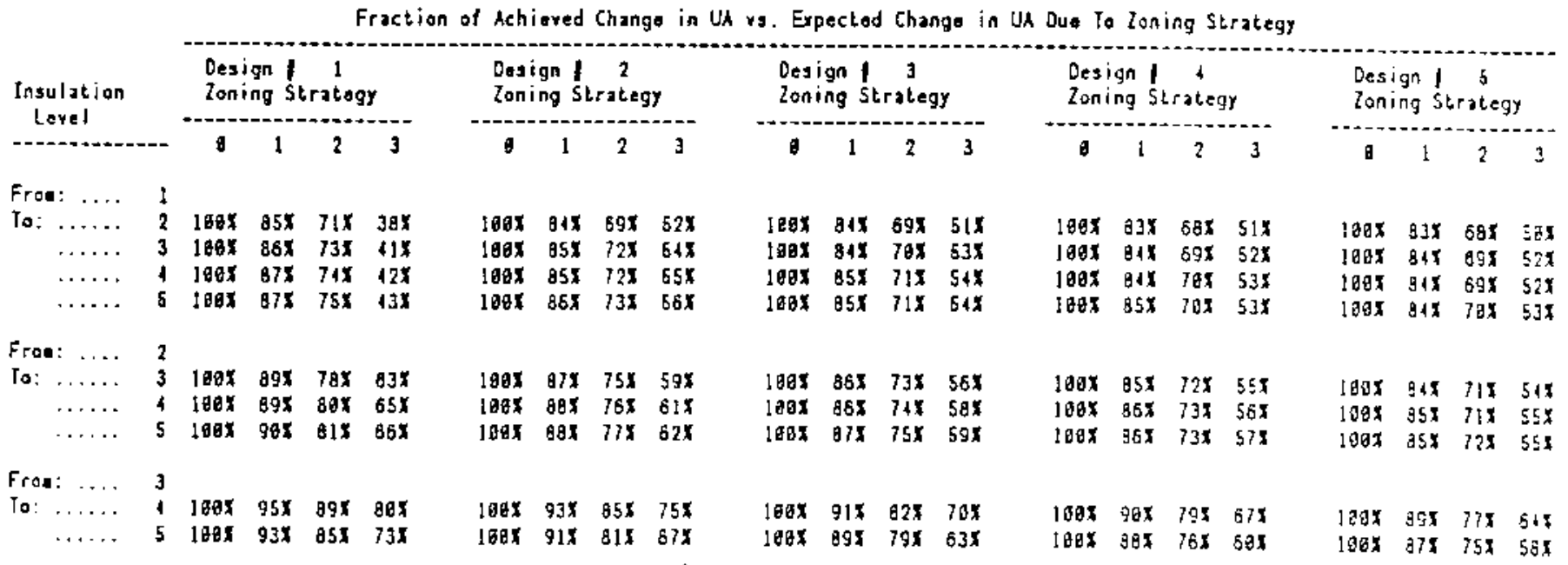





\subsection{CONCLUSIONS}

The thermal analysis on the Hood River end-use metered data leads to several conclusions. This sample includes single-family homes (about 73\%), multifamity residences (about $6 \%$ ), and manufactured homes (about $21 \%$ ). The homes with enough data to permit thermal characterization tend to be those that are reportedly relying on electric space heat. of the end-use metered homes in the HRCP, about $60 \%$ could not be characterized--predominantly because of the large number of days that wood-burning equipment appears to be in use. Several conclusions were reached concerning the 113 sites characterized using the metered data:

- The difference in annualized estimated consumption (ACE) for space heating per square foot of conditioned floor area, before and after retrofit for the combined sample, represents a $24 \%$ reduction in consumption in the pre-retrofit level of space heating requirements. The single-family homes and multifamily homes show the greatest reduction (approximately $30 \%$ each) in $\mathrm{kWh} / \mathrm{ft}^{2}-\mathrm{yr}$ postretrofit. Manufactured homes show only one-third the savings of a a single-family home.

- The changes in heat loss coefficients (UA) and effective heatingdegree-days, derived from the linear fits of the heating data to inside-outside temperature difference show a total savings similar to that of the AEC estimates.

- The mean difference in floor area-normalized space heating requirements for the combined sample is $2.05 \mathrm{kWh} / \mathrm{ft}^{2}-\mathrm{yr}$. Singlefamily reductions averaged $2.24 \mathrm{kWh} / \mathrm{ft}^{2}-\mathrm{yr}$, multifamily units averaged $2.48 \mathrm{kWh} / \mathrm{ft}^{2}-\mathrm{yr}$, and manufactured homes averaged 1.28 $\mathrm{kWh} / \mathrm{ft}^{2}-\mathrm{yr}$.

- The mean reduction in total consumption for the combined sample is $2432 \mathrm{kWh} / \mathrm{yr}$. Single-family reductions averaged $2899 \mathrm{kWh} / \mathrm{yr}$, multifamily units $1900 \mathrm{kWh} / \mathrm{yr}$, and manufactured homes $991 \mathrm{kWh} / \mathrm{yr}$.

- Space heating consumption estimates performed using Seattle TMY data for the Hood River single-family homes show that pre-retrofit levels of consumption are similar to those for the ELCAP climate zone-1 Residential Base homes, and that post-retrofit consumption levels are very similar to those for the ELCAP climate zone-1 RSDP control homes that represent current construction practice. 
- The change in the as-operated UAs for the combined sample is a $20 \%$ reduction over the mean pre-retrofit level. The shift upward in balance temperature difference represents a $9 \%$ increase for the combined sample. The changes in as-operated UA and balance temperature differences for the single-family homes and multifamily units are greater than those of the combined sample by several percentage points. The manufactured homes show less than half the decrease observed in the single-family, as-operated UAs and demonstrate little change in the balance temperature differences over pre-retrofit levels.

- Although a change upward is noted in the mean heating season inside temperatures, it is less than $0.5^{\circ} \mathrm{F}$. Given the change in asoperated UAs, this temperature change is not large enough to suggest higher thermostat set points in the post-retrofit heating season.

- In homes that burned wood, wood usage dropped by $27 \%$ after the installation of weatherization measures. Heater usage also went down but only by about 14\%. For this group of homes it appears that the greatest share of the savings was receovered in reduced wood-stove usage, although a significant reduction in space heating was also observed.

- Mean annual electrical space heat savings are less than half of the savings initially projected. The weather normalized estimates provided by this work are for homes assuming no wood-stove usage.

\subsection{RECOMMENDED ADDITIONAL ANALYSES}

Our analyses show that reduction in wood use is a factor contributing to the low achieved savings fraction and that thermostat takeback is not likely. However, our discussions about zoning are, at best, plausible explanations and, at worst, pure speculation. The vast unexplained difference between predicted and actual savings demands further explanation. We suggest several additional analyses to further the understanding of the Hood River homes.

These additional analyses follow, in roughly prioritized order:

1. Reproduce the pre- and post-retrofit UAs and space heating consumption estimates for the end-use metered Hood River homes using the SHLM. The lack of this information largely limits examinations of baseline estimates to conjecture. By comparing the predicted loads with measured loads, the contribution of errors in baseline consumption estimates could be placed in proper perspective. Additionally, comparing theoretical and empirical UAs would shed light on the issues of in-situ retrofit performance. 
2. Estimate the hot water savings in the end-use metered homes. This would result in more accurate space heat savings estimates from Hirst's data on billing totals.

3. Evaluate total pre- and post-retrofit consumption in the end-use metered homes. This would ensure that our analyses of space heating in those homes were not influenced by changes in other end uses.

4. Evaluate the electric space heating consumption in the end-use metered homes not included in this report (the wood-burning homes). This would allow a closer match to Hirst's definitions of woodburning building classes and strengthen the conclusions regarding wood displacement.

5. Analyze, in detail, the hourly and seasonal wood heating and indoor air temperature patterns in the end-use metered homes. This would further verify or refute our conclusions regarding wood heating takeback, and provide additional knowledge as to the nature of the phenomenon and how it might be accounted for in future conservation projects. 



\subsection{REFERENCES}

Drost, M. K., P. W. Zimmerman, R. J. Skarda, and E. W. Pearson. 1987. Analysis of Thermal Performance Data Taken Under the Residential Standards Demonstration Program. PNL-6021, Pacific Northwest Laboratory, Richland, Washington.

Fels, M. F. 1984. The Princeton Scorekeeping Method: An Introduction. PU/CEES-163, Princeton University, Center for Energy and Environmental Studies, Princeton, New Jersey.

Hirst, E. 1987. Cooperation and Community Conservation. DOE/BP-11287-18, Oak Ridge National Laboratory, Oak Ridge, Tennessee.

Le Baron, B. A. 1988. Wood Stove Use in the ELCAP Residential Base Sample. PNL-6713, Pacific Northwest Laboratory, Richland, Washington.

Stoval1, T. K. 1987. Hood River Conservation Project Load Analysis. ORNL/CON-240, Oak Ridge National Laboratory, Oak Ridge, Tennessee. 
" 


\section{DISTRIBUTION}

No. of

Copies

OFFSITE

2 DOE/Office of Scientific and Technical Information

2 R. A. Gillman Bonneville Power Administration End-Use Research Section

P.0. Box 3621-RPEE

Portland, OR 97208

M. E. Taylor

Bonneville Power Administration

End-Use Research Section

P.0. Box 3621-RPEE

Portland, OR 97208

W. M. Warwick

Battelle Portland office

$500 \mathrm{NE}$ Multnomah, Suite 650

Portland, OR 97232
No. of

Copies

ONSITE

13 Pacific Northwest Laboratory

N. E. Miller

R. G. Pratt

W. F. Sandusky (4)

G. M. Stokes

Publishing Coordination

Technical Report Files (5) 
